\title{
Bringing multiple values to the table: assessing future land-use and climate change in North Kona, Hawai i
}

\author{
Leah L. Bremer ${ }^{1,2,3}$, Lisa Mandle ${ }^{4}$, Clay Trauernicht ${ }^{5}$, Pua ala Pascua $^{5}$, Heather L. McMillen ${ }^{1,6}$, Kimberly Burnett ${ }^{2}$, Christopher A. \\ Wada $^{2}$, Natalie Kurashima ${ }^{1,7}$, Shimona A. Quazi ${ }^{1}$, Thomas Giambelluca ${ }^{8}$, Pia Chock $^{7}$ and Tamara Ticktin $^{1}$
}

\begin{abstract}
As ecosystem service assessments increasingly contribute to decisions about managing Earth's lands and waters, there is a growing need to understand the diverse ways that people use and value landscapes. However, these assessments rarely incorporate the value of landscapes to communities with strong cultural and generational ties to place, precluding inclusion of these valuesalongside others - into planning processes. We developed a process to evaluate trade-offs and synergies in ecosystem services across land-use scenarios and under climate change in North Kona, Hawai i, a tropical dry ecosystem where water, fire, biodiversity, and cultural values are all critical considerations for land management decisions. Specifically, we combined participatory deliberative methods, ecosystem service models, vegetation surveys, and document analysis to evaluate how cultural services, regulating services (groundwater recharge, landscape flammability reduction), biodiversity, and revenue: (1) vary across four land-use scenarios (pasture, coffee, agroforestry, and native forest restoration) and (2) are expected to vary with climate change (representative concentration pathway (RCP) 8.5 mid-century scenario). The native forest restoration scenario provided high cultural, biodiversity, and ecosystem service value, whereas coffee's strongest benefit was monetary return. The agroforestry scenario offered the greatest potential in terms of maximizing multiple services. Pasture had relatively low ecological and economic value but, as with native forest and agroforestry, held high value in terms of local knowledge and cultural connection to place. Climate change amplified existing vulnerabilities for groundwater recharge and landscape flammability, but resulted in few shifts in the ranking of land-use scenarios. Our results demonstrate that cultural services need not be sacrificed at the expense of other management objectives if they are deliberately included in land-use planning from the start. Meaningfully representing what matters most to diverse groups of people, now and under a changing climate, requires greater integration of participatory methods into ecosystem service analyses.
\end{abstract}

Key Words: agroforestry; ahupua'a; cultural services; ecosystem services; forest restoration; hydrologic services; islands; landscape flammability; land-use change; watershed management

\section{INTRODUCTION}

In an era of global environmental change, one of the most pressing issues is identifying land management practices that meet societal needs now and into the future. Institutions are responding to this need through calls to incorporate ecosystem services (ES) into decision making and planning (Guerry et al. 2015). The emergence of the Intergovernmental Platform on Biodiversity and Ecosystem Services and a memorandum directing United States federal agencies to explicitly incorporate ES into decision making exemplify this trend (Donovan et al. 2015, Mooney 2016). Implementing these policy advances requires consideration of the costs and benefits of land management decisions in terms of the outcomes most important to diverse stakeholders. This has spurred the movement of ES science from theory to application in land-use planning and decision making (Raudsepp-Hearne et al. 2010, Ruckelshaus et al. 2015). Yet, despite rapid advancement in ES science and application, interdisciplinary assessments of the effects of land-use change on multiple benefits and stakeholder groups remain scarce (Asah et al. 2014, Kenter 2016, Pascual et al. 2017).

Ecosystem services assessments also increasingly diverge between those focusing on sociocultural values of local communities vs. those focusing on assessing and valuing provisioning and regulating services (Kenter 2016). Cultural ecosystem services (CES) or the "non-material benefits people obtain from ecosystems" (Millenium Ecosystem Assessment (MEA) 2005: 40), represent one pathway to include local perceptions of landscape values in ES assessments. The importance of CES is increasingly recognized (Daniel et al. 2012, Gould et al. 2014), but incorporating CES alongside other values into decision making remains highly limited (Raudsepp-Hearne et al. 2010, Chan et al. 2012). Most CES assessments focus on recreation and scenic beauty (Chan et al. 2012) and do not adequately capture the value of landscapes to the many communities worldwide with strong cultural, generational, and genealogical ties to land (Liu and Opdam 2014). This includes traditionally managed production landscapes (based on place-specific agroecological practices and knowledge transmitted and adapted through generations), which are widespread globally, including over $10 \%$ (96 million ha) of cultivated land in the developing world (Altieri 2004) and an estimated 11\% (377 million ha) of global forests (White and Martin 2002). In these systems, cultural background, worldview, and attachment to place play particularly important roles in the way CES are realized and perceived (Winthrop 2014, Pascua et al. 2017). There is a critical gap in studies that include CES alongside other ES in these contexts where cultural values

\footnotetext{
${ }^{1}$ Department of Botany, University of Hawai'i at Mānoa, ${ }^{2}$ University of Hawai'i Economic Research Organization, University of Hawai i at Mānoa, ${ }^{3}$ Water Resources Research Center, University of Hawai'i at Mānoa, ${ }^{4}$ The Natural Capital Project, Woods Institute for the Environment and Department of Biology, Stanford University, ${ }^{5}$ Department of Natural Resources and Environmental Management, University of Hawai'i at Mānoa, ${ }^{6}$ USDA Forest Service, Northern Research Station, NYC Urban Field Station, ${ }^{7}$ Kamehameha Schools, ${ }^{8}$ Department of Geography, University of Hawai'i at Mānoa
} 
are often most appropriately assessed through participatory, deliberative methods (Kenter et al. 2011, Raymond et al. 2014).

Understanding of how ES will be influenced by climate change also remains limited in broader ES assessments (Biggs et al. 2012, Runting et al. 2016), despite being critical to managing these services over time (Mooney et al. 2009). Rising temperatures and changing rainfall patterns have consequences for multiple services, and varying trade-offs across different land uses are also anticipated (Kirchner et al. 2015, Runting et al. 2016). Cultural ecosystem services may be affected by climate change, but some CES - such as attachment to place, maintenance of social networks, reciprocity, and local ecological knowledge-also contribute to community resilience to climate change and other disturbances (Folke 2006, Vaughan and Vitousek 2013, McMillen et al. 2014). This emphasizes the importance of integrating CES alongside other ES into land-use planning under climate change.

In response to these gaps, we collaborated with the Kamehameha Schools (KS; an indigenous Hawaiian educational trust and the State of Hawai'i's largest private landowner) and an indigenous Hawaiian (Kānaka Maoli) and place-based (kama'āina) community to develop a process to assess the multiple environmental, economic, and cultural outcomes of land use and climate change and apply it in an existing decision context in North Kona, Hawai i. Since the late 18 th century, much of North Kona's dry forest has been converted to pasture for cattle, a land use with strong cultural value but declining monetary returns (Melrose et al. 2016). Over 300,000 ha of pasturelands remain in Hawai i i, but increasing concerns over water scarcity, fire risk, and low native biodiversity raise the issue of alternative land-use options (Melrose et al. 2016). Such decisions are occurring together with a resurgence in the application of indigenous principles to land and marine resource management for diverse ecological, socioeconomic, and cultural values (e.g., Hawai'i Department of Land and Natural Resources (DLNR) 2012, Kamehameha Schools 2016).

We sought to inform an upcoming decision around the use of pasturelands in North Kona, as well as provide a framework for $\mathrm{KS}$ and other landowners with similar interests in balancing revenues with broader cultural and environmental values. This collaboration defined four broad future land-use scenarios for pasturelands: (i) pasture (i.e., current use); (ii) coffee, a lucrative but water-intensive land use common in the vicinity; (iii) native forest restoration; and (iv) agroforestry, a historically important land use across the Pacific that integrates understory crops with high-value (cultural and economic) native and nonnative tree crops (Bell and Taylor 2015). We then assessed and compared a range of outcomes across these scenarios that were explicitly tied to concerns identified by the landowner and the local community. These outcomes included net revenue streams for the land manager, indigenous cultural and community values, and ES that are relevant statewide: groundwater recharge, fire risk reduction, and native biodiversity.

Using a range of interdisciplinary methods, we address the following questions: (i) What are the cultural, environmental, and revenue outcomes associated with each land-use scenario? (ii) What are the synergies and trade-offs across land-use scenarios? and (iii) How does incorporating changing climate conditions affect these synergies and trade-offs?

\section{METHODS}

\section{Study site: social-ecological setting}

Ka'ūpūlehu is an ahupua'a (a traditional sociopolitical land boundary) situated on the leeward coast of Hawai'i Island, extending from sea level to $2500 \mathrm{~m}$ and covering $104 \mathrm{~km}^{2}$ (Fig. 1). Mean annual rainfall (MAR) is $666 \mathrm{~mm} /$ year and projected to decrease by $18-25 \%$ by midcentury (Giambelluca et al. 2013, Elison Timm et al. 2014). Sparsely vegetated lava fields cover about one-third of the low elevation area, and a large portion of the area used for agriculture prior to European contact is now Hualālai Cattle Ranch. Currently, most of $\mathrm{Ka}$ ūpūlehu is rural and sparsely populated (12 dwellings at midelevation), but there is a luxury residential development (part-time, transient population of 55) and hotel (243 rooms) at the shoreline. Few lineal descendants and longtime residents of Ka'ūpūlehu are able to reside within the ahupua'a, but many live nearby, maintaining strong connections to their ancestral lands (McMillen et al. 2016).

The entire ahupua'a is owned by KS. As a trust established for the benefit of Kānaka Maoli, KS seeks to manage 365,000 acres of land statewide to balance multiple economic, educational, cultural, and environmental goals (Goldstein et al. 2012, Kamehameha Schools 2016). Alongside other landowners across the State, KS is considering future options for pasturelands and seeks to develop a process to incorporate diverse values into decision making across their landholdings. Thus, Ka'ūpūlehu provided an opportunity to directly support a timely decision context while also developing an approach widely applicable for landowners interested in incorporating multiple values into landuse decisions (County of Hawai'i 2010, Bremer et al. 2015).

Cultural and place-based values are of high priority for KS in Ka'ūpūlehu, and Kānaka Maoli and kama'āina of Ka'ūpūlehu (henceforth local community) are involved in resource management advisory councils, educational programs, and cultural restoration projects in the ahupua'a. Environmental outcomes, including groundwater recharge (the main water source statewide), are also highly valued by $\mathrm{KS}$ and the broader public. Wildfires are a primary concern and have increased dramatically in Hawai $i$ in recent decades with the expansion of nonnative grasslands, especially in drier areas including North Kona (Trauernicht et al. 2015). Finally, the ahupua'a contains some of State's last remaining tracts of tropical dry forest, considered to be the most endangered ecosystem in Hawai'i (Bruegmann 1996, Cordell et al. 2008) due to habitat conversion, fire, and invasive species (Blackmore and Vitousek 2000). Climate change-related reductions in precipitation and increased temperatures are projected to further reduce groundwater recharge, increase wildfire risk, and threaten native biodiversity (Elison Timm et al. 2014, Vorsino et al. 2014, Elison Timm 2017).

\section{Land management and climate change scenarios}

Our study area focused on the midelevation portion of Ka ūpūlehu classified as perennial grassland in the widely utilized LANDFIRE land cover data set (LANDFIRE 2012; $13.9 \mathrm{~km}^{2}$; Fig. 1). We defined future land-use scenarios for this area through discussions with KS and the local community as well as through broader consideration of pasturelands in North Kona. This included several in-person meetings with the Natural and Cultural Resources team of $\mathrm{KS}$ (four to five KS staff and four to five 
Fig. 1. Land-use scenarios under the current and future climate (RCP 8.5 midcentury) for pasturelands in Ka'ūpūlehu ahupua'a. (a) pasture (current and future climate); (b) Hawaiian agroforestry (current and future climate); (c) native forest restoration (current climate); (d) coffee (current climate); (e) native forest restoration (future climate); (f) coffee (future climate). The area suitable for coffee is reduced under climate change given temperature constraints. The type of forest restored (dry vs. mesic) also shifts under climate change with changes in precipitation. Agroforestry and pasture extent and composition do not change within the range of precipitation changes.

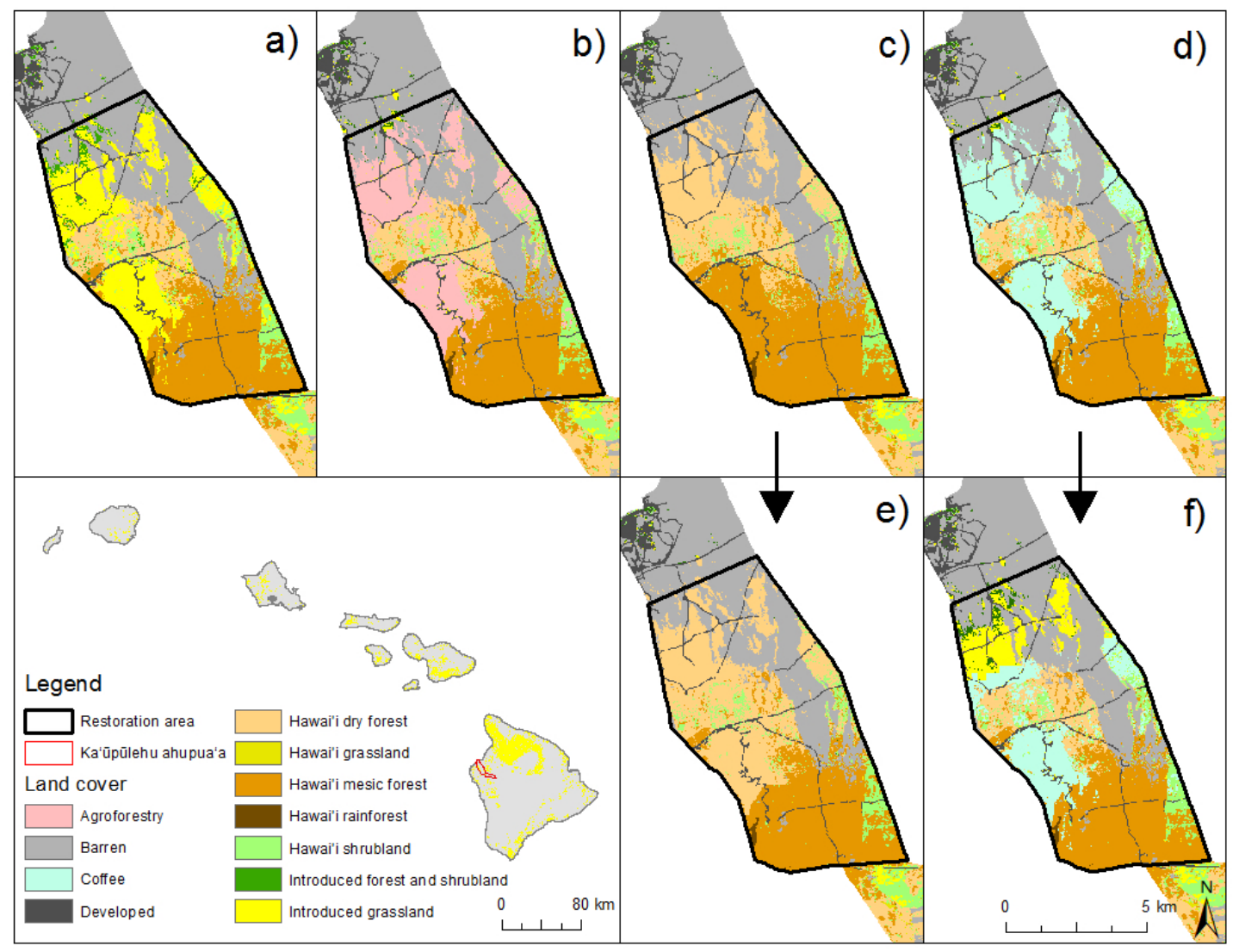

researchers) and two community workshops (including the CES workshop described below and one presenting preliminary results). This iterative process allowed for refinement of scenarios to better match KS and community goals. The final land-use scenarios considered were: (1) pasture (current use); (2) native forest restoration in all current pasture areas (mesic or dry forest; Append. 1); (3) agroforestry (mesic or dry based on MAR; Append. 1); and (4) coffee, in areas with suitable temperature ranges (Fig. 1; Append. 1). Within the second scenario, forest restoration type, which depended on MAR, shifted under climate change (Append. 1). Coffee was limited to areas with mean annual temperatures $>15^{\circ} \mathrm{C}$ and $<22.8^{\circ} \mathrm{C}$ (Bittenbender and Smith 2008), constraining coffee to $13.6 \mathrm{~km}^{2}$ under the current climate and to $8.9 \mathrm{~km}^{2}$ under climate change (Fig. 1; Append. 1).

We compared outcomes (see below) of these land-use scenarios under current and projected climate conditions. Future climate under the representative concentration pathway (RCP) 8.5 midcentury (2065) scenario entails an $8.5 \mathrm{~W} / \mathrm{m}^{2}$ increase in radiative forcing from preindustrial levels and a $2^{\circ} \mathrm{C}$ rise in average global temperatures by $2046-2065$. Initially considered extreme, we are already expected to overshoot the RCP 8.5 scenario (Sanford et al. 2014). Accordingly, the current climate provides a low-range potential future climate, and RCP 8.5 midcentury a useful mid to upper range.

Our analysis was over 50 years, in line with the midcentury climate projection. We selected environmental, cultural, and economic values that will likely be important to KS, the local community, and broader society over this time period.

\section{Cultural, environmental, and economic outcomes}

\section{Cultural ecosystem services}

Given KS's mission to benefit Kānaka Maoli communities, we focused our assessment of CES on the local Kānaka Maoli community with cultural and generational ties to Ka ūpūlehu, as well as other kama'āina residents and stewards of Ka'ūpūlehu. Our epistemological approach emphasizes an indigenous 
Hawaiian worldview. All research was conducted with institutional review board (IRB) approval from the University of Hawai'i at Mānoa following standard protocols for prior informed consent. Equally importantly, interactions followed culturally appropriate protocols, particularly when discussing elder knowledge and ancestral landscapes (See Pascua et al. 2017; Append. 1). The findings and analyses reported here include and build upon a 2-year collaborative research project on local knowledge and adaptation to change (Ka'ūpūlehu Community et al. 2014, McMillen et al. 2016; McMillen, "Local knowledge and adaptation to environmental and climate change in Ka ūpūlehu," unpublished manuscript).

We evaluated CES important for the local community and their associations with different land-use scenarios through a community workshop and in-depth interviews. We used purposive sampling for our community workshop (Tongco 2007), where 13 local community members were selected for their in-depth and long-term relationships to Ka üpūlehu and the surrounding North Kona region. Given that KS specifically aims to perpetuate indigenous cultural values, we included those who are highly knowledgeable about place-based practices and are actively involved in efforts to perpetuate traditional practices and sustainable resource management (Pascua et al. 2017). Although the number of workshop participants was small, Ka'üpūlehu is sparsely populated (permanent resident population of ca. 30), and the workshop included representation from most families of lineal descendants currently living in the region.

The community workshop used facilitation tools to enhance collaboration (Ching 2014). We employed participatory and deliberative methods that allow for social interaction and discussion, which are considered effective in bringing attention to shared values and concepts (Kenter 2016). This included an activity where participants were asked to write responses on blank index cards to the question: "What are the ways you interact with/ are sustained by 'āina (land, literally "that which feeds")?" Workshop participants then shared the answers, and as a group, categorized these answers in a deliberative process. In another activity, subgroups discussed specific land-use scenarios, followed by a larger group discussion, with the guiding questions: "What are the ways you interact with this particular type of 'aina? What specific things maintain your relationship to this type of 'āina?" Participants also discussed what would be missing if the given land-use scenario was no longer present (see Pascua et al. 2017 for full methods).

For a deeper understanding of themes that emerged from the workshop, open-ended, indepth interviews were carried out with 10 of the workshop participants at a subsequent community gathering (three of the original workshop participants were unavailable). Interview questions followed up on workshop themes and also asked specifically about perceptions of changes in CES under climate change. Data collected in the community workshops and follow-up interviews were compiled and then analyzed through inductive or open coding, a qualitative method that combs responses for emergent services and themes (Maxwell 2005). Cultural ecosystem services associated with each land use were organized into four overarching categories: (1) 'Ike (knowledge); (2) Mana (spirituality); (3) Pilina Kānaka (social interactions); and (4) Ola Mau (physical and mental well-being) following a Hawai'i-based CES framework developed in a participatory process with indigenous scholars and two local communities in Hawai'i (see Pascua et al. 2017; Table 1).

The assessment of CES focused on the land uses in Ka'üpulehu as well as the broader North Kona region. This represents a different spatial scale than the environmental and economic analyses (which focused specifically on Ka ūpūlehu only). Although ideally the spatial scale of all analyses would exactly match, for a variety of reasons this was not possible in this study. Despite strong ancestral and cultural ties to Ka ūpūlehu among the local community, they do not have direct decision-making power or open access to these lands. Thus, focusing more broadly on the land-use type, including the lands they currently manage within the broader area, resonated more with workshop participants. Challenges in spatially allocating sociocultural values, particularly in indigenous communities, have been noted elsewhere (Kenter et al. 2015).

\section{Groundwater recharge}

As the Kona region has virtually no surface flow (Brauman et al. 2014), we estimated the ecosystem service of groundwater recharge following Wada et al. (2017) for Ka'ūpūlehu under the different land-use scenarios for the current spatial extent (13.9 $\mathrm{km}^{2}$ ) of pasturelands using a water balance approach where:

Recharge $=$ Rainfall + fog interception - actual evapotranspiration (AET)

We used MAR from the Hawai' i rainfall atlas (Giambelluca et al. 2013) for the current climate and statistically downscaled rainfall data for RCP 8.5 midcentury for the future climate (Elison Timm et al. 2014). We estimated fog interception using the relationship described in Engott (2011), which estimates fog as a function of elevation, vegetation, and rainfall (Append. 1). To calculate annual AET across the region, we created linear regressions by land cover, with AET as a function of annual vegetation and climate variables (air temperature, net radiation, relative humidity, wind speed, available soil moisture, leaf area index, canopy cover, and vegetation height) (Giambelluca et al. 2014) and adjusted parameters and equations with climate and landuse change (Wada et al. 2017; Append. 1). Within Ka'ūpūlehu, the difference between AET produced by Giambelluca et al. (2014) and the statistical approach described above was $<5 \%$.

\section{Landscape flammability}

To assess how land use influences fire occurrence in Ka'ūpūlehu pasturelands today, we used a 20-year (1992-2011) data set of the spatial extent of 91 fires, collected by the Hawai i Wildfire Management Organization (Append. 1). Random points were sampled annually across the landscape $(n=150,000$, mean $n=$ 7500 or $0.23 \%$ of the landscape per year) and classified as burnt or unburnt depending on whether they occurred within the perimeter of a fire during the sample year. The burnt/unburnt classification was used as a binomial response to fit a generalized additive model (GAM) of the probability of fire occurrence per pixel per year (e.g., Preisler et al. 2004, Trauernicht et al. 2012) as a function of landscape-scale drivers of fire (Pausas and Keeley 2009). Predictors included annual rainfall, mean annual temperature, aspect, vegetation type, wildfire ignition density, and annual rainfall anomaly (the difference between annual and mean annual rainfall; Append. 1). 
Table 1. Examples of cultural services discussed by workshop participants associated with land-use types (categories based on Hawai'i CES framework (Pascua et al. 2017))

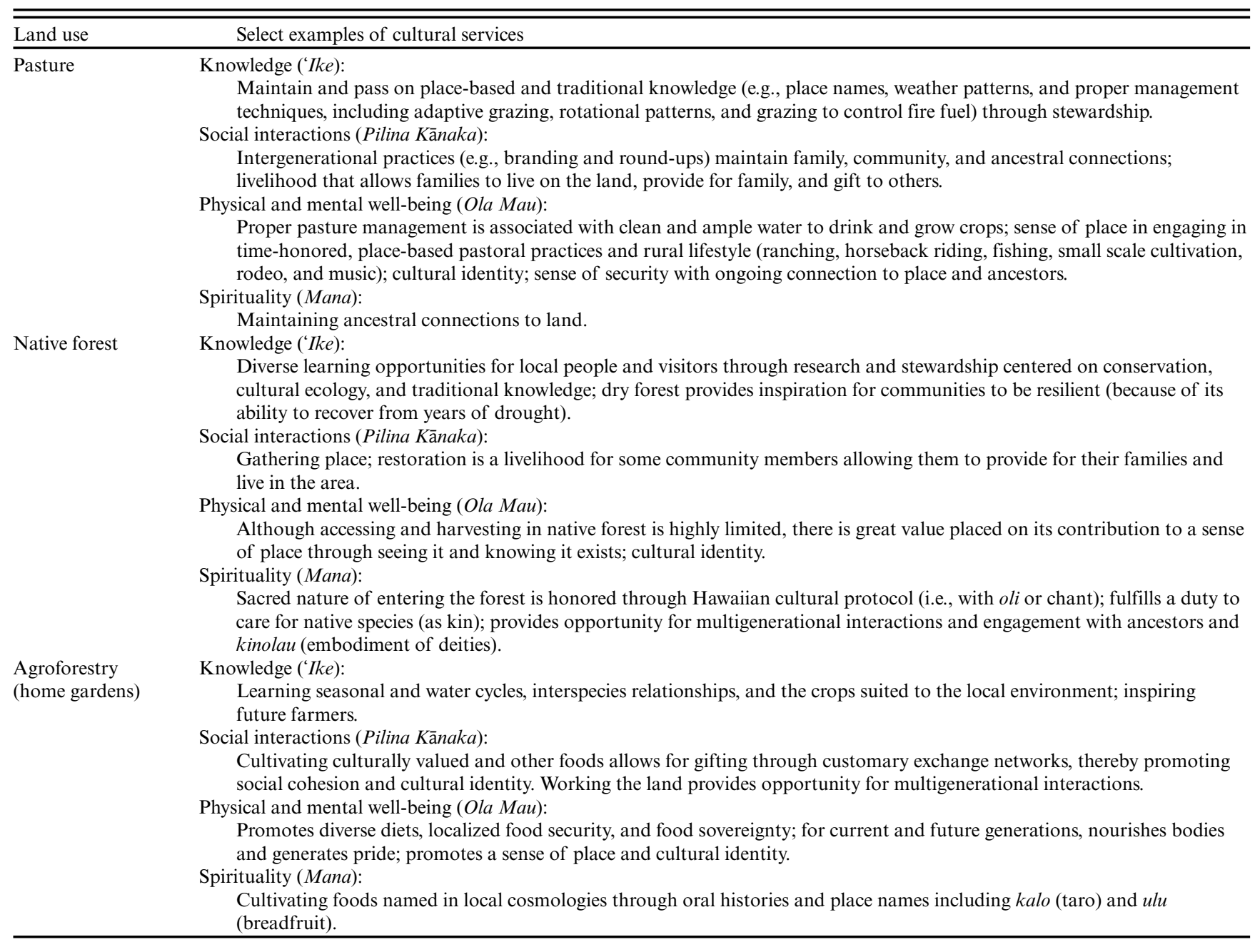

We characterized changes in landscape flammability by comparing distributions of the annual, per pixel probability of fire occurrence across the management area, as predicted by the model above, under the different land-use scenarios for current and future climates. For the given land-use scenarios, grassland flammability predictions were used to characterize pasture, forest flammability to characterize native forest restoration and agroforestry, and shrubland flammability to characterize coffee. There are anecdotal accounts of fires occurring in coffee plantations in Hawai $i$; however, the limited distribution of the crop in the study region precluded integrating a coffee land-cover type as a predictor.

\section{Biodiversity conservation value}

To assess biodiversity conservation value, we measured native and nonnative plant species richness and cover in pasture, native forest, and coffee in Ka'ūpūlehu and the surrounding area (Append. 1). Given that there is currently no traditional agroforestry practiced in or near $\mathrm{Ka}$ 'ūpūlehu, estimates of species richness and cover were developed for a potential agroforestry scenario based on expert knowledge of agroforestry systems practiced historically in Ka'ūpūlehu and those currently practiced in similar environments elsewhere in the Pacific Islands. This included a mix of native species, traditional (Polynesian introduced) crops, and other species with high economic and cultural value (Append. 1). We did not assess the effect of projected climate change on biodiversity conservation value because of the lack of information available on how vegetation in each land use will respond to climate change.

\section{Management costs and returns to land manager}

To consider the potential revenue implications of various land uses, we used publicly available data on growing parameters, costs, and revenues for each of the land-use scenarios. Hawai' i-specific data were used wherever possible. When not available, we used national statistics, often from the United States Department of Agriculture Natural Agricultural Statistics Service (Append. 1). The net present value (NPV) of management costs and economic returns to the landowner/manager for each scenario was calculated over 50 years, assuming a discount rate of $5 \%$. Costs 
included the labor and materials required to convert the existing landscape (pasture) to each land-use scenario, as well as the labor, inputs, and materials needed to maintain production or conservation (e.g., fencing, export costs, wages). All values are reported in 2015 U.S. dollars. Inflation adjustments are made using the Bureau of Labor Statistics inflation calculator. Detailed explanation and assumptions behind the calculation of costs and revenue for each scenario are outlined in Append. 1.

\section{RESULTS}

\section{Cultural ecosystem services \\ "When we describe ourselves as the child of the land, we have every obligation to the land that we do to our Tūt $\overline{\mathrm{u}}$ [grandparent ]..."}

Local community members who participated in our study emphasized the interconnections among the four categories of CES as well as among provisioning, regulating, and cultural services (Table 1). They described a suite of values for pasture, agroforestry, and the forest restoration sceanarios, which were categorized to the extent possible as: Mana (spiritual values); 'Ike (knowledge); Ola Mau (physical and mental health); and Pilina Kānaka (social connections) (Pascua et al. 2017; Table 1). References to the importance of the other benefits assessed in this study (e.g., fire control, water availability, native species, and economics in terms of livelihoods) also emerged in discussions of cultural values (Table 1). Coffee is not discussed here; although cultivated in Ka ūpūlehu, it was deemed by workshop participants as neither culturally nor ecologically suitable given its recent arrival, small scale, and high irrigation requirements.

Participants discussed cultural "services" in the context of reciprocal relationships between humans and the 'âina, or land, rather than a unidirectional flow of benefits toward people. This reflects family traditions and current lifestyles, which fluidly move from the mountains to the sea across shoreline, pasture, forest, and home gardens. They spoke of shaping and being shaped by healthy "ancestral landscapes" and "storied landscapes" as the basis for sustenance of body, mind, spirit, and cultural identity. Therefore, maintaining a connection to the land is critical, and participants framed the value of human-environment relationships through concepts of environmental kinship (land as family_-äina as 'ohana), responsibility (kuleana) and stewardship (mālama 'āina). For example, they described themselves as children of the land (kama'āina or keiki o ka 'āina), underscoring the kinship they feel to place and how their identities are tied to the land and to interactions with it.

Features of the landscape are named, cared for, and revered as family members. The land encodes history, teachings, and provides inspiration as well as physical, emotional, and spiritual well-being. The land flourishes when people live upon and interact with it. Participants explained that lessons from these storied places (wahi pana) and their associated oral histories (mo'olelo) impart the importance of sharing with others, respect, knowing one's place in the universe, and how to use resources wisely. In an interview from earlier phases of the research, one woman, who was also a workshop participant, talked about her relationship with the storied landscape:

\begin{abstract}
"Just for me to be in that petroglyph field to go and sit amongst them and learn and ask questions and connect with kūpuna (elders) in that way."
\end{abstract}

In terms of perceptions of climate change effects on CES, decreases in rainfall were associated with reducing the already limited capacity to graze and water cattle. Less rain, and potentially more fire, could also decrease the health and extent of native forest, which participants thought would diminish its educational, social, and cultural value. Likewise, less rain and more fire was thought to diminish potential agricultural returns. Participants also pointed to increases in the frequency and intensity of extreme events (e.g., drought, hurricanes, tidal waves) as critical environmental stressors requiring continuous community-based adaptation. This relies on continued access to and engagement with 'āina.

\section{Groundwater recharge}

The pasture scenario provided the greatest benefits in terms of groundwater recharge under current climate conditions (3521 millions of liters per year (MLPY)), followed by native forest restoration (3351 MLPY), agroforestry (2850 MLPY), and coffee (-2850 MLPY). The negative water balance of coffee was due to irrigation needs surpassing precipitation. Among these scenarios, pasture yielded significantly more recharge than agroforestry (24\%), and coffee resulted in significantly less recharge than all other scenarios (179\% less water than pasture; Fig. 2; Append. 1).

Fig. 2. Groundwater recharge (rainfall + fog interception - ET) in millions of liters per year under the current climate and a future climate (RCP 8.5 midcentury) under different land-use scenarios. Error bars = one standard deviation of error associated with ET estimates.

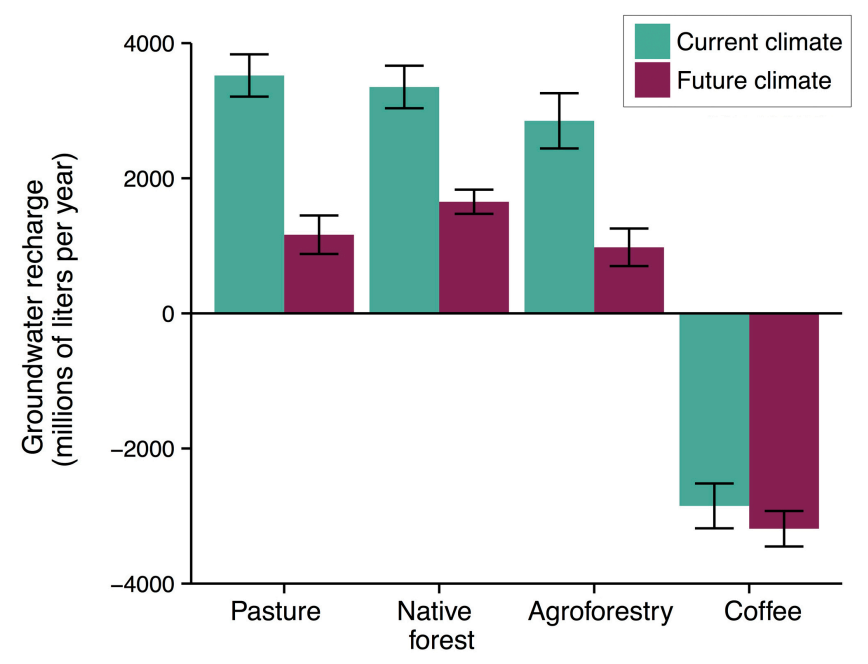

Under climate change, recharge decreased significantly (12-67\%) across all land-use scenarios (Fig. 2). This decrease was mainly driven by reductions in rainfall (Append. 1). Native forest provided significantly more recharge than both pasture $(42 \%$ more water) and agroforestry (58\% more water), and coffee continued to provide substantially less recharge than the other

Erratum: In the original publication the units used in Fig. 2 differed from those in the text. The figure was corrected on 28 May 2020. This change does not affect the meaning or accuracy of the information presented. 
land uses under a future climate despite a 35\% reduction in suitable cultivation area ( $>350 \%$ less water than pasture; Fig. 2 ; Append. 1).

\section{Landscape flammability}

Under the current climate, the annual area burned varies highly year to year across the study region $\left(0->1100 \mathrm{~km}^{2} /\right.$ year $)$. Of the dominant land-cover classes, grassland, shrubland, and forest accounted for $51 \%, 21 \%$, and $18 \%$, respectively, of the area burned across the landscape. For the fire occurrence models, the global GAM was the best supported (Akaike weight $>0.99$; explained deviance $=25.9 \%$ ), which included all the explanatory variables listed above. The relatively low explained deviance was expected, given the low temporal resolution of our predictors and high variability across the multiple drivers that influence wildfire occurrence, especially the predominance of human-caused ignitions in Hawai'i (Trauernicht et al. 2015).

Landscape flammability was largely determined by the interaction between rainfall and land cover. Flammability was lowest for native forest and agroforest restoration, followed by coffee and pasture under current climatic conditions (Fig. 3). These patterns were driven by the occurrence of a peak in flammability along the rainfall gradient that differed among vegetation types (Append. 1). In other words, flammability was reduced at the wettest and driest sites, which constrain fuel ignitability and availability, respectively (Murphy et al. 2011), but these constraints varied among vegetation types (Fig. 3). Based on observed landscape-scale fire occurrence, fire probability for grasslands was highest (ca. 0.04) and peaked at drier conditions (450 mm MAR) when compared with shrublands (ca. 0.02 at 650 mm MAR) and forest (ca. 0.015 at $650 \mathrm{~mm}$ MAR).

Fig. 3. Landscape flammability (the distribution of the per pixel probability of annual fire occurrence) under different land-use scenarios, based on grassland flammability predictions to characterize pasture, forest flammability to characterize native forest and agroforest (combined), and shrubland flammability to characterize coffee. The center lines indicate median values, the box indicates lower (25th) and upper (75th) quartiles, and the whiskers indicate minimum and maximum values.

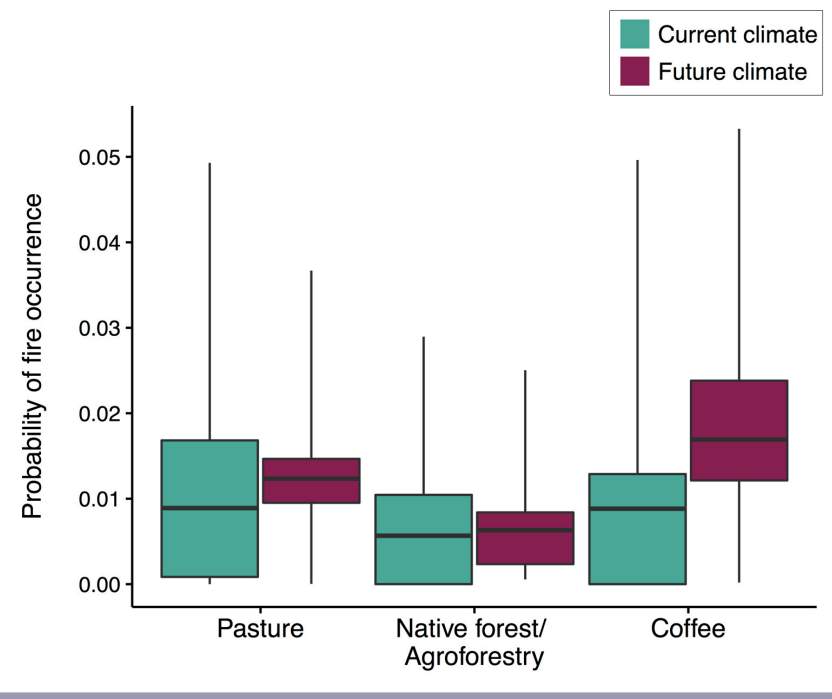

Climate change increased flammability across the entire watershed under all scenarios. Within the proposed restoration area (Fig. 3), land-use scenarios differed in terms of future fire occurrence risk. Climate change reduced the variability of per pixel fire probability across all scenarios, and reduced the maximum fire probability for pasture and forest. Median per pixel fire probability increased for both pasture and coffee scenarios, with a dramatic upward shift in flammability across the restoration area for coffee under climate change. In contrast, native forest (and agroforest) restoration exhibited negligible change in the median and a reduction in the maximum and upper quartile values for per pixel fire probability under the projected changes in mean annual rainfall and temperature.

\section{Biodiversity conservation value}

The native forest restoration scenario had the highest richness of native species, highest native species cover, and lowest invasive species cover (Fig. 4; Append. 1). Compared with native forest, the agroforestry scenario was anticipated to include approximately $60 \%$ of native tree and shrub species richness and less than half as many native herbaceous species. Native forest and agroforestry had similar proportions of endemic tree and shrub species (ca. $80 \%$ of trees and shrub species were endemic), but agroforestry had a lower proportion of endemic herbaceous species. As the agroforestry scenario involved mostly nonnative understory crops, it also had much lower native understory cover than the forest. Coffee and pasture both had no native species, but pasture had the most nonnative species in both the overstory and understory. Pasture also had very high cover of invasive species (mostly invasive grasses).

\section{Management costs and returns to landowner}

Agroforestry provided the greatest monetary returns to the landowner (NPV of $\$ 646.1$ million over 50 years; Fig. 5c), with coffee yielding about a third of the net revenue as agroforestry (\$226.9 million; Fig. 5e), and pasture providing much lower returns (\$382,804; Fig. 5a). Ninety-two percent of anticipated agroforestry revenue came from inclusion of figs (Ficus carica) as a crop; without figs, agroforestry would still yield more than pasture, but substantially less than coffee (Fig. 5d). Native forest restoration had a negative NPV (-\$5.90 million; Fig. 5b), which reflects restoration costs only because we did not quantify the cultural and ecological benefits provided by native forest restoration in monetary terms. Due to reduced suitable area, NPV for coffee dropped to $\$ 148.5$ million (Fig. 5e) under the future climate. This constituted a $35 \%$ reduction from the current climate scenario, but coffee remained the second most profitable land use. Other landuse extents were not affected by climate change as forest, agroforestry, and pasture were all suitable across both current and future temperature and precipitation ranges.

\section{DISCUSSION AND CONCLUSIONS}

In the context of our study area, the landowner (KS) seeks to make decisions that incorporate cultural, economic, community, educational, and environmental values, making this an ideal and practical case study to develop a method to consider multiple values in decision making. These results provide insight and a framework for private land managers in Hawai' $i$ and beyond whose decisions have broad societal outcomes that increasingly need to be considered alongside private benefits (Reddy et al. 2015). Our results highlight the importance of integrating diverse values 
Fig. 4. Native and nonnative species richness $(\mathrm{a}, \mathrm{c})$ and vegetation cover $(\mathrm{b}, \mathrm{d})$ by land use. Values are means $\pm 1 \mathrm{SE}$. Nonnative species richness includes both introduced and invasive species.

a)

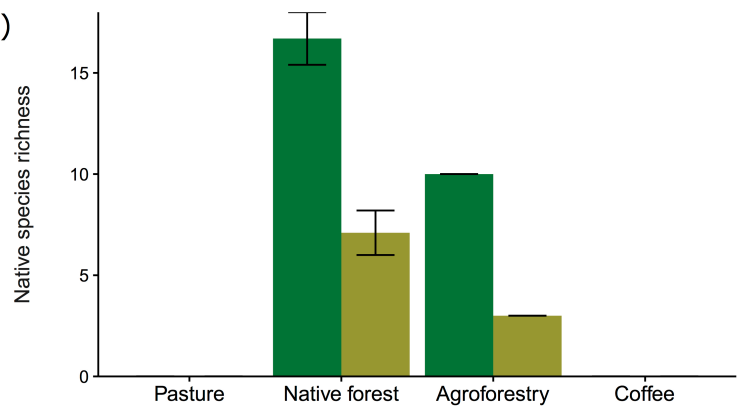

c)

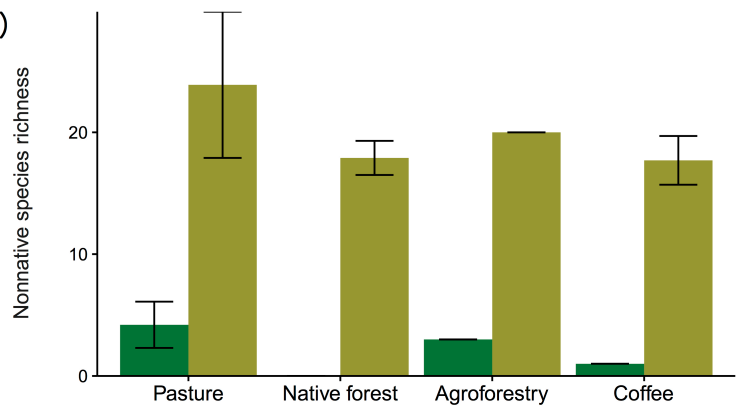

b)

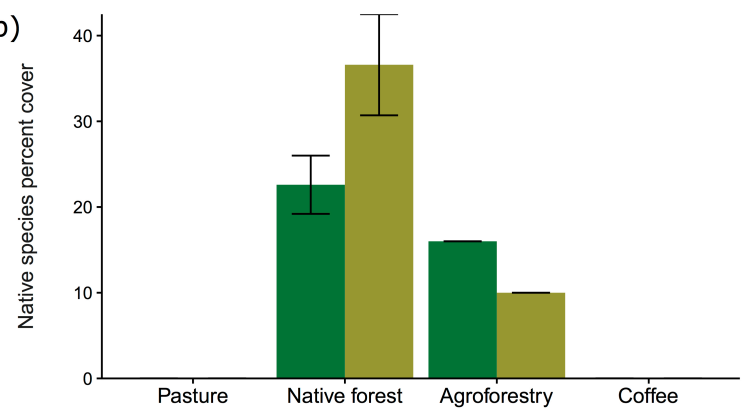

d)

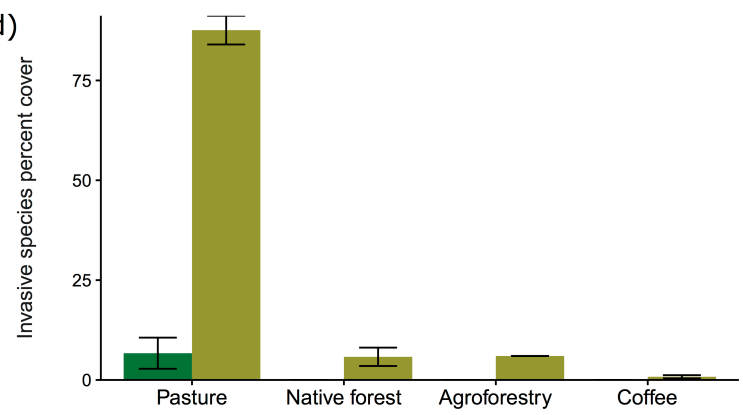

Overstory Understory because conclusions about preferred land uses can change depending on the values considered. This includes cultural values, which, if incorporated into land-use planning from the beginning, need not be sacrificed at the expense of other objectives. Our results also demonstrate that, at least for this study area, climate change amplifies existing concerns over groundwater recharge and landscape flammability, but only results in small shifts in rankings of land-use scenarios. Finally, many of the CES brought forth in our discussions are also indicators of community resilience (e.g., cultural connection to place, social connections, local ecological knowledge), which will be fundamental in adapting to these changes (McMillen et al. 2016).

\section{Framing cultural services as shared relational values deepens understanding of the sociocultural benefits associated with different land-use options}

Local community perspectives on CES clearly demonstrate that land-use options need to be assessed not only in terms of the benefits flowing from land to people, but also in terms of reciprocal relationships to place (Chan et al. 2016). Incorporating CES through participatory methods provided insight that deepened and altered the story told by ecological and economic indicators alone. The deliberative process of identifying and documenting shared values was meaningful in and of itself, and provides a voice for place-based and indigenous perspectives in decision making (Pascua et al. 2017). This supports the idea that "deliberation is crucial for value formation, it is not just a means but an end in itself, as a catalyst for new democratic spaces" (Kenter 2016: 180).

We found strong cultural value in all four categories associated with pasture, agroforestry, and native forest restoration (Table 1).
For example, native forest included high spiritual value (Mana) and provided opportunities for learning through caring for native species ('Ike - knowledge). However, the value of native forest restoration is not fully realized due to limited access to current North Kona native forest areas, which are largely within private land and a State reserve. Agroforestry was particularly valued for its potential contribution to health (Ola Mau) through promoting diverse diets and local food security, as well as reciprocity and social relationships through sharing of food and perpetuating a sense of place (Pilina Kanaka - social interactions).

For many families in the area, the ability to perpetuate social relationships and cultural connections to ancestral and storied landscapes through stewardship is of utmost importance to their identity and way of life. As a key example, pasture and ranching provide important opportunities to maintain and pass down place-based knowledge and cultural practices ('Ike - knowledge) that facilitate a sense of place and strong connections among families, communities, and ancestors (Pilina Kanaka - social interactions and Mana - spirituality). Ranching also provides physical and mental health benefits (Ola Mau) from the sense of well-being, place, and identity brought by perpetuating long-term practices. Pasture also represents an alternative to encroaching real estate development, which the local community views as the greatest threat to their values and way of life. However, through just an ecological and economic lens, pasture provides relatively low value (Fig. 6). Ignoring critically important cultural values may have consequences for the well-being of the local community, and may reduce public support for land-use policy (Asah et al. 2014). 
Fig. 5. Annual revenue and costs through time for (a) pasture; (b) native forest; (c) agroforestry (with figs); (d) agroforestry (no figs); and (e) coffee under current climate (solid line) and under climate change (dotted line).

a)

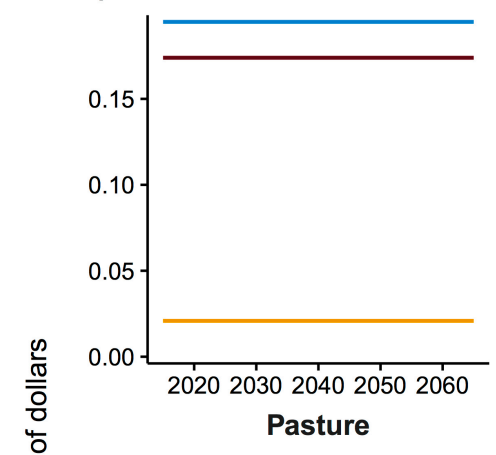

d)

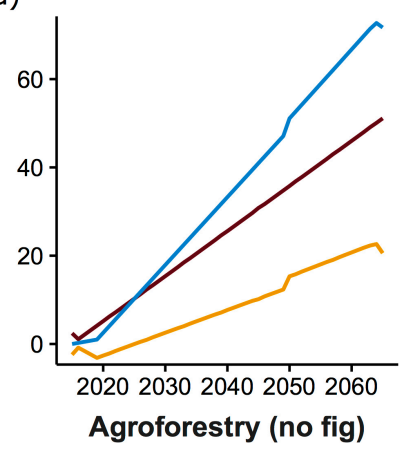

b)

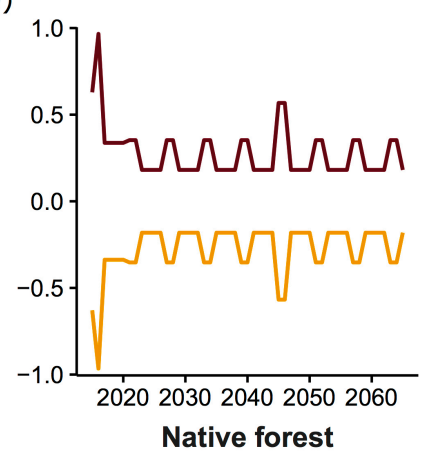

e)

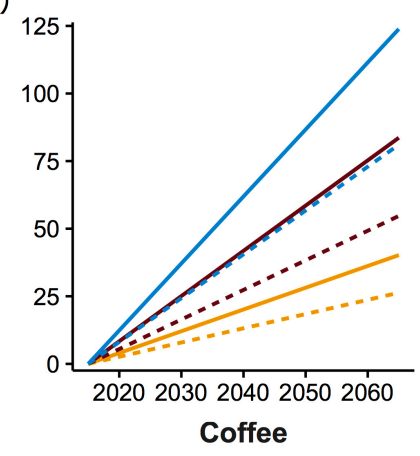

c)

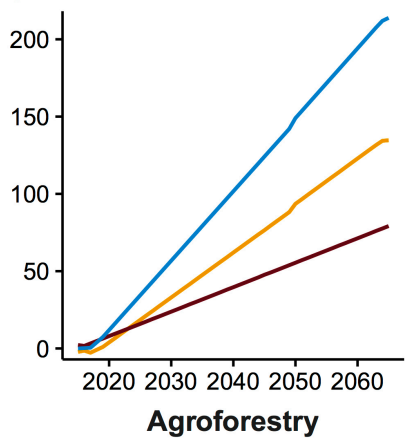

- Total revenue

- Total costs

- Net revenue

- Current climate

-.. Future climate

Fig. 6. Synergies and trade-offs in outcomes across land-use scenarios for net revenue, water, fire, and biodiversity). Axis values indicate the land-use scenario rank (among pasture, nature forest restoration, agroforestry, and coffee), with 4 indicating the greatest benefit and 1 the lowest benefit. Cultural ecosystem services and values tied to each scenario are outlined in detail in Table 1.

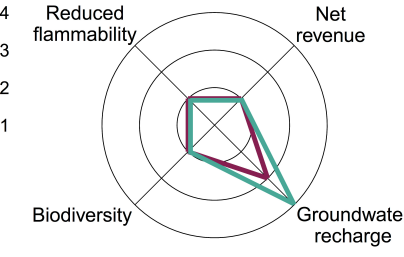

Pasture

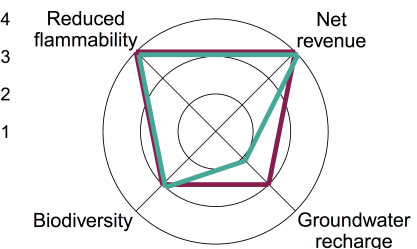

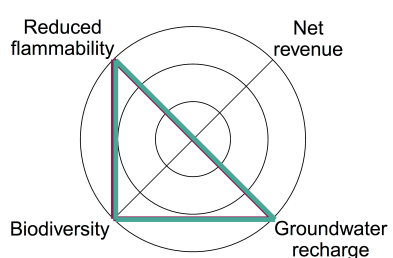

Native forest

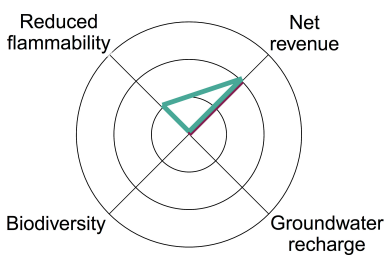

Groundwater

Agroforestry

Synergies and trade-offs among multiple benefits

Land-use options can be ranked comparatively based on environmental and revenue outcomes, illuminating the compatabilities and trade-offs associated with each decision now and under climate change (Fig. 6). If managing only for environmental values, for example, native forest restoration performs best across the benefits considered, whereas coffee meets the least of these criteria (Fig. 6). If emphasis is instead placed on monetary returns to the private landowner, the top scenarios are agroforestry and coffee, with native forest restoration ranking last (Fig. 6). These results do not provide clear win-win answers for a landowner like KS, but, depending on how different objectives are weighted, can be used to articulate the synergies and trade-offs among multiple desired outcomes. However, in this context, CES represent deep place-based and indigenous values that should be incorporated as integral components of the planning process from the outset, rather than as outcomes that might be traded off (Table 1; Pascua et al. 2017).

Pasture, agroforestry, and native forest restoration all resulted in similar benefits for groundwater recharge, whereas coffee resulted in significantly less, due to high irrigation needs (Append. 1). In contrast to global studies on reforestation and afforestation that show decreases in water availability with conversion to forest (Bosch and Hewlett 1982, Farley et al. 2005), we found that dry forest restoration would have very little effect on groundwater recharge compared with pasture. Our results are similar to those found in the Kona region (Brauman et al. 2012), suggesting that 
reforestation can be compatible with hydrological service goals in areas where forest evapotranspiration rates are low, and where fog interception increases precipitation under forest cover.

Native forest restoration and agroforestry provided the lowest landscape flammability under the current climate, whereas pasture posed the greatest risk, followed closely by coffee. However, managing fire in these systems also requires mitigating the risk of fire incursion from the broader landscape, so mitigation may be more intensive for native forest restoration and agroforestry (e.g., requiring fuel breaks) than pasture, where targeted grazing can be used to reduce fire risk (Nader et al. 2007). Local ranching families of Ka ūpūlehu, for example, view grazing as an important fire control strategy. From their perspective, native forest (or agroforestry) is at high fire risk if fencing prevents cattle from reducing fuel loads by grazing.

Our results suggest that investing in agroforestry restoration can have important ecological and economic benefits (Fig. 6), andif designed with cultural values in mind - can also support CES. Agroforestry systems were once widespread across the Hawaiian Islands, and there is an increasing interest in restoring them to improve Hawaii's food security and revitalize a culturally important land use (Kurashima et al. 2017). Although our agroforestry system was hypothetical, it has potential to conserve at least half of the native and/or endemic species found in native forest, which is consistent with studies of Pacific Island agroforests elsewhere (Raynor 1993, Thaman 2014). Given the economic returns to the landowner, agroforestry can also represent a strategy to finance native forest restoration. Fig, a nonnative species, was included in the agroforestry scenario at the suggestion of the local community to make a traditional land use more economically viable in a contemporary context. Incorporating high-value cash crops into traditional agroforestry systems is a common strategy practiced worldwide to increase the economic returns of systems that provide food security, cultural resources, and ecological services. Although fig provides the highest expected revenue, including other crops (e.g., sweet potato) ensures positive economic returns, even if the local demand for figs falls short of planned production.

Given the high cultural value placed on native forest restoration, pasture, and agroforestry, a mix of these land uses will likely produce the most socially acceptable land-use decision. A key limitation of the current study lies in its focus on single-use scenarios. It was beyond the scope of this study to explore the broad range of scenarios that could emerge through an iterative process. However, our approach provides KS with a process to evaluate multiple outcomes, and our results detail the types of services that would emerge from a mixture of land uses. A useful next step in KS's planning process would be to explore scenarios, jointly determined by $\mathrm{KS}$ and community values that combine different land uses.

\section{Integrating climate change into decisions}

A recent review highlighted the paucity of studies that integrate both land use and climate change into assessments of ES provision for improved decision making (Runting et al. 2016). Our results suggest that climate change primarily acts as an amplifier of existing natural resource concerns with negative outcomes for groundwater and fire risk in our study area. In the case of coffee, for example, the combined impact of climate change and a crop that is more water intensive and susceptible to fire, made coffee cultivation an increasingly less feasible land-use option in dry areas where substantial irrigation is needed and where fire risk is increasing.

Climate change also resulted in several shifts in land-use priorities (Fig. 6). First, in contrast to current climate conditions, native forest restoration provided more groundwater recharge under climate change than pasture (Fig. 2). This is largely due to drier conditions requiring a greater proportion of the management area be restored to dry forest (which has lower evapotranspiration rates than mesic forest) (Giambelluca et al. 2014; Append. 1). Second, in the case of landscape flammability, coffee posed a higher risk than pasture under climate change, but not under the current climate. This is due to the differing effects of rainfall on the peak flammability of shrublands (coffee) and grasslands (pasture) in the restoration area under climate change (Append. 1).

We lacked the information needed to project how species richness and cover of Hawaiian plant communities will respond to climate change. Existing research has shown that climate change is expected to lead to declines in those species currently at highest risk of extinction (Fortini et al. 2013), including the many currently threatened and endangered endemic species found in the region (Vorsino et al. 2014). The relative ranking of scenarios for biodiversity conservation is therefore unlikely to change, but the level of biodiversity conserved is likely to be reduced under climate change. Thus, Fig. 6 reflects no change in the ranking of land-use scenarios for the biodiversity outcome, but we put this forward as an important area for future research.

From the perspective of the local community, climate change would not change the fundamental CES associated with pasture, agroforestry, and native forest. There was, however, concern about possible reductions in the extent of suitable areas for these practices. Importantly, participants further identified extreme or pulse events (e.g., hurricanes), and the timing of natural cycles (e.g., regional drought and flooding) as important influences on CES and adaptation strategies. Climate change will likely increase the frequency and intensity of events and alter the timing of rainfall and other cycles (Intergovernmental Panel on Climate Change 2014), but we were not able to adequately capture these outcomes in our current ES models. Increasing the temporal resolution of both ES models and climate projections to capture the effects of pulse or extreme events as well as participatory research on how these events influence humanenvironment relationships represent fruitful areas for future research.

Interestingly, human-environment relationships were discussed by participants not only in terms of current well-being, but in terms of resilience and capacity to adapt to climate and other environmental stressors. Indeed, many of the CES identified by community participants are also considered important components of social resilience, including reflective and shared learning, cultural identity, traditional ecological knowledge, social organization, stewardship, reciprocity, and physical and mental well-being (Berkes and Ross 2013, Cabel and Oelofse 2012, McMillen et al. 2016; Table 1). Access to and reciprocal relationships with 'aina are the foundation for adaptive capacity, because it is through cooperative action to steward natural- 
cultural resources that traditional and place-based knowledge continues to be generated and transmitted and to evolve (McMillen et al. 2016). Thus, the social resilience embedded in the CES associated with maintaining relationships with multiple land uses also underpins the community's ability to adapt and maintain their relationships to place in the face of change. Decision making needs to include a foundational awareness of and support for communities to continue to learn and adapt while applying their place-based knowledge, beliefs, and practices (McMillen et al. 2016).

In Ka'ūpūlehu, and across communities with strong cultural, multigenerational, and/or genealogical land ties, considering cultural and community values, including connection to place, is critical to supporting land-use decisions that provide benefits now and in an uncertain future (Maher and Baum 2013). In addition to the environmental benefits assessed, the cultural values associated with native forest, agroforest, and pasture reflect what often matter most to people in this and other communities with strong cultural connections to their land. Collectively, this research demonstrates the necessity of integrating locally relevant evaluations of CES alongside other environmental and economic benefits into ES assessments and land-use planning in order to improve inclusive and equitable decision-making capacity under changing climate conditions.

Responses to this article can be read online at: http://www.ecologyandsociety.org/issues/responses. $\mathrm{php} / 9936$

\section{Acknowledgments:}

We are deeply grateful to kama'āina of $\mathrm{Ka} \mathrm{a}^{\mathrm{u}} \mathrm{u} p \overline{\mathrm{u}} \mathrm{lehu}$ for their time, insight, and support of this project. We also thank the Kamehameha Schools, particularly the Natural and Cultural Resources Team, for their support and input into project design. P. Hamel and B. Bryant provided support for the uncertainty analyses; P. Hoppe assisted with botanical analyses; $M$. Lucas carried out geospatial data processing of fire data; and the Hawai $i$ Wildfire Management Organization provided fire history data. We thank $H$. Mooney, G. Daily, A. Guswa, the UH Mānoa NSF Coastal SEES team, and the Natural Capital Project Freshwater and Terrestrial Team for their helpful comments throughout the project. This research was supported by the National Science Foundation Coastal SEES Program (\#SES-1325874) and the Pacific Island Climate Change Cooperative.

\section{LITERATURE CITED}

Altieri, M. A. 2004. Linking ecologists and traditional farmers in the search for sustainable agriculture. Frontiers in Ecology and the Environment 2(1):35-42. http://dx.doi.org/10.1890/1540-9295 (2004)002[0035:LEATFI]2.0.CO;2

Asah, S. T., A. D. Guerry, D. J. Blahna, and J. J. Lawler. 2014. Perception, acquisition and use of ecosystem services: human behavior, and ecosystem management and policy implications. Ecosystem Services 10:180-186. http://dx.doi.org/10.1016/j. ecoser.2014.08.003
Bell, J., and M. Taylor. 2015. Building climate-resilient food systems for Pacific Islands. Program report: 2015-15. WorldFish, Penang, Malaysia.

Berkes, F., and H. Ross. 2013. Community resilience: toward an integrated approach. Society and Natural Resources 26(1):1-16. http://dx.doi.org/10.1080/08941920.2012.736605

Biggs, R., M. Schlüter, D. Biggs, E. L. Bohensky, S. BurnSilver, G. Cundill, V. Dakos, T. M. Daw, L. S. Evans, K. Kotschy, A. M. Leitch, C. Meek, A. Quinlan, C. Raudsepp-Hearne, M. D. Robards, M. L. Schoon, L. Schultz, and P. C. West. 2012. Toward principles for enhancing the resilience of ecosystem services. Annual Review of Environment and Resources 37(1):421-448. http://dx.doi.org/10.1146/annurev-environ-051211-123836

Bittenbender H. C., and V. E. Easton. 2008. Growing coffee In Hawai $i$. College of Tropical Agriculture and Human Resources, University of Hawai'i at Mānoa, Hawai'i.

Blackmore, M., and P. M. Vitousek. 2000. Cattle grazing, forest loss, and fuel loading in a dry forest ecosystem at Puu Wa'aWa'a Ranch. Biotropica 32:625-632. http://dx.doi.org/10.1646/0006-3606 (2000)032[0625:CGFLAF]2.0.CO;2

Bosch, J. M., and J. D. Hewlett. 1982. A review of catchment experiments to determine the effect of vegetation changes. Journal of Hydrology 55:3-22. http://dx.doi.org/10.1016/0022-1694(82) 90117-2

Brauman, K. A., D. L. Freyberg, and G. C. Daily. 2012. Land cover effects on groundwater recharge in the tropics: ecohydrologic mechanisms. Ecohydrology 5(4):435-444. http:// dx.doi.org/10.1002/eco.236

Brauman, K. A., D. L. Freyberg, and G. C. Daily. 2014. Impacts of land-use change on groundwater supply: ecosystem services assessment in Kona, Hawaii. Journal of Water Resources Planning and Management 140:146-159.

Bremer, L. L., J. M. S. Delevaux, J. J. K. Leary, L. J. Cox, and K. L. L. Oleson. 2015. Opportunities and strategies to incorporate ecosystem services knowledge and decision support tools into planning and decision making in Hawaili. Environmental Management 55(4):884-899. http://dx.doi.org/https://doi.org/10.1007/ s00267-014-0426-4

Bruegmann, N. M. 1996. Hawai' i’s dry forests. Endangered Species Bulletin 11:26-27.

Cabel, J. F., and M. Oelofse. 2012. An indicator framework for assessing agroecosystem resilience. Ecology and Society 17(1): 18. http://dx.doi.org/10.5751/ES-04666-170118

Chan, K. M. A., P. Balvanera, K. Benessaiah, M. Chapman, and S. Díaz. 2016. Why protect nature? Rethinking values and the environment. Proceedings of the National Academy of Sciences United States of America 113(6):1462-1465. http://dx.doi. org/10.1073/pnas.1525002113

Chan, K. M. A., A. D. Guerry, P. Balvanera, S. Klain, T. Satterfield, and X. Basurto. 2012. Where are cultural and social in ecosystem services? A framework for constructive engagement. Bioscience 62(8):744-756. http://dx.doi.org/10.1525/bio.2012.62.8.7

Ching, D. 2014. Facilitating strategic thinking and planning. Workshop manual. Pacific Center for Collaboration, Honolulu, Hawaii, USA. 
Cordell, S., M. Mcclellan, Y. Y. Carter, and L. J. Hadway. 2008. Towards restoration of Hawaiian tropical dry forests: the Kaupulehu outplanting programme. Pacfiic Conservation Biology 14:279-284. http://dx.doi.org/10.1071/PC080279

County of Hawai'i. 2010. Hawaii County water use and development plan update. Final report, Department of Water Supply, County of Hawaii, Honolulu, Hawaii. [online] URL: http://files.hawaii.gov/dlnr/cwrm/planning/wudpha2012.pdf

Daniel, T. C., A. Muhar, A. Arnberger, O. Aznar, J. W. Boyd, K. M. a. Chan, R. Costanza, T. Elmqvist, C. G. Flint, P. H. Gobster, A. Gret-Regamey, R. Lave, S. Muhar, M. Penker, R. G. Ribe, T. Schauppenlehner, T. Sikor, I. Soloviy, M. Spierenburg, K. Taczanowska, J. Tam, and A. von der Dunk. 2012. Contributions of cultural services to the ecosystem services agenda. Proceedings of the National Academy of Sciences United States of America 109(23):8812-8819. http://dx.doi.org/10.1073/pnas.1114773109

Donovan, S., C. Goldfuss, and J. Holdren. 2015. Incorporating ecosystem services into federal decision making. Federal memorandum, U.S. Government, Washington, D.C., USA. [online] URL: https://obamawhitehouse.archives.gov/sites/default/ files/omb/memoranda/2016/m-16-01.pdf

Elison Timm., O. 2017. Future warming rates over the Hawaiian Islands based on elevation-dependent scaling factors. International Journal of Climatology 37(S1):1093-1104. http://dx. doi.org/10.1002/joc.5065

Elison Timm, O., T. W. Giambelluca, and H. F. Diaz. 2014. Statistical downscaling of rainfall changes in Hawai'i based on the CMIP5 global model projections. Journal of Geophysical Research: Atmospheres 120:92-112. http://dx.doi.org/https://doi. org/10.1002/2014JD022059

Engott, J. A. 2011. A water-budget model and assessment of groundwater recharge for the Island of Hawai $i$. Scientific Investigations Report 2011-5078, U.S. Geological Survey, Washington, D.C., USA.

Farley, K. A., E. G. Jobbágy, and R. B. Jackson. 2005. Effects of afforestation on water yield: a global synthesis with implications for policy. Global Change Biology 11(10):1565-1576. http://dx. doi.org/10.1111/j.1365-2486.2005.01011.x

Folke, C. 2006. Resilience: the emergence of a perspective for social-ecological systems analyses. Global Environmental Change 16:253-267. http://dx.doi.org/10.1016/j.gloenvcha.2006.04.002

Fortini, L., J. Price, J. Jacobi, A. Vorsino, J. Burgett, K. W. Brinck, F. Amidon, S. Miller, S. 'Ohukani`ohi`a Gon III, G. Koob, and E. Paxton. 2013. A landscape-based assessment of climate change vulnerability for all native Hawaiian plants. Technical report TR HCSU-044, Hawaii Cooperative Studies Unit, University of Hawaii, Hilo, Hawaii, USA.

Giambelluca, T. W., Q. Chen, A. G. Frazier, J. P. Price, Y.-L. Chen, P.-S. Chu, J. K. Eischeid, and D. M. Delparte. 2013. Online rainfall atlas of Hawai'i. Bulletin of American Meteorological Society 94:313-316. http://dx.doi.org/10.1175/BAMS-D-11-00228.1

Giambelluca, T. W., X. Shuai, M. L. Barnes, and R. J. Alliss. 2014. Evapotranspiration of Hawai $i$. Final report. U.S. Army Corps of Engineers, Honolulu District, and Commission on Water
Resource Management, State of Hawai i, Honolulu, Hawai i, USA. [online] URL: http://evapotranspiration.geography.hawaii. edu/assets/files/PDF/ET\%20Project $\% 20$ Final $\% 20$ Report.pdf

Goldstein, J. H., G. Caldarone, T. K. Duarte, D. Ennaanay, N. Hannahs, G. Mendoza, S. Polasky, S. Wolny, and G. C. Daily. 2012. Integrating ecosystem-service tradeoffs into land-use decisions. Proceedings of the National Academy of Sciences of the United States of America 109(19):7565-7570. http://dx.doi. org/10.1073/pnas.1201040109

Gould, R. K., N. M. Ardoin, U. Woodside, T. Satterfield, N. Hannahs, and G. C. Daily. 2014. The forest has a story: cultural ecosystem services in Kona, Hawai'i. Ecology and Society 19 (3):55. http://dx.doi.org/https://doi.org/10.5751/ES-06893-190355

Guerry, A. D., S. Polasky, J. Lubchenco, R. Chaplin-Kramer, G. C. Daily, R. Griffin, M. Ruckelshaus, I. J. Bateman, A. Duraiappah, T. Elmqvist, M. W. Feldman, C. Folke, J. Hoekstra, P. M. Kareiva, B. L. Keeler, S. Li, E. McKenzie, Z. Ouyang, B. Reyers, T. H. Ricketts, J. Rockström, H. Tallis, and B. Vira. 2015. Natural capital and ecosystem services informing decisions: from promise to practice. Proceedings of the National Academy of Sciences 112(24):7348-7355. http://dx.doi.org/10.1073/pnas.1503751112

Hawai i Department of Land and Natural Resources (DLNR). 2012. Ka $\bar{u} \bar{u}$ forest reserve management plan. State of Hawai $i$ Department of Land and Natural Resources, Honolulu, Hawai i, USA. [online] URL: http://dlnr.hawaii.gov/forestry/files/2013/02/ Kau_FR_Mgnt_Plan_2012.pdf

Intergovernmental Panel on Climate Change (IPPC). 2014. Climate change 2014: synthesis report. Contribution of Working Groups, 1, 11 and 111 to the Fifth Assessment Report of the IPPC, Geneva, Switzerland.

Ka'ūpūlehu Community, H. McMillen, T. Ticktin, and N. Kurashima. 2014. Ka'ūpūlehu local ecological knowledge and climate change portal. [online] URL: http://hbmpweb.pbrc. hawaii.edu/kaupulehu/

Kamehameha Schools. 2016. Kūhanauna: a generation on the rise. Kamehameha Schools strategic plan 2015-2020. Kamehameha Schools, Honolulu, Hawai'i, USA. [online] URL: http://www. ksbe.edu/sp2020/

Kenter, J. O. 2016. Editorial: shared, plural and cultural values. Ecosystem Services 21:175-183. http://dx.doi.org/10.1016/j. ecoser.2016.10.010

Kenter, J. O., T. Hyde, M.Christie, and I. Fazey. 2011. The importance of deliberation in valuing ecosystem services in developing countries - evidence from the Soloman Islands. Global Environmental Change 21:505-521. http://dx.doi. org/10.1016/j.gloenvcha.2011.01.001

Kenter, J. O., L. O’Brien, N. Hockley, N. Ravenscroft, I. Fazey, K. N. Irvine, M. S. Reed, M. Christie, E. Brady, R. Bryce, A. Church, N. Cooper, A. Davies, A. Evely, M. Everard, R. Fish, J. A. Fisher, N. Jobstvogt, C. Molloy, J. Orchard-Webb, S. Ranger, M. Ryan, V. Watson, and S. Williams. 2015. What are shared and social values of ecosystems? Ecological Economics 111:86-99. http://dx.doi.org/https://doi.org/10.1016/j.ecolecon.2015.01.006

Kirchner, M., J. Schmidt, G. Kindermann, V. Kulmer, H. Mitter, F. Prettenthaler, J. Rüdisser, T. Schauppenlehner, M. Schönhart, 
F. Strauss, U. Tappeiner, E. Tasser, and E. Schmid. 2015. Ecosystem services and economic development in Austrian agricultural landscapes - the impact of policy and climate change scenarios on trade-offs and synergies. Ecological Economics 109:161-174. http://dx.doi.org/10.1016/j.ecolecon.2014.11.005

Kurashima, N., Jeremiah, J., and T. Ticktin. 2017. I Ka Wā Ma Mua: the value of a historical ecology approach to ecological restoration in Hawai'i. Pacific Science 71(4):437-456. http://dx. doi.org/10.2984/71.4.4

Liu, J., and P. Opdam. 2014. Valuing ecosystem services in community-based landscape planning: introducing a wellbeingbased approach. Landscape Ecology 29(8):1347-1360. http://dx. doi.org/10.1007/s10980-014-0045-8

Maher, T. M., and S. D. Baum. 2013. Adaptation to and recovery from global catastrophe. Sustainability 5(4):461-1479. http://dx. doi.org/10.3390/su5041461

Maxwell, J. 2005. Qualitative research design: an interactive approach. Sage Publications, Thousand Oaks, California, USA. http://dx.doi.org/10.1093/obo/9780199756810-0126

McMillen, H. L., T. Ticktin, A. Friedlander, S. D. Jupiter, R. Thaman, J. Campbell, and J. Veitayaki. 2014. Small islands, valuable insights: systems of customary resource use and resilience to climate change in the Pacific. Ecology and Society 19 (4): 44. http://dx.doi.org/10.5751/ES-06937-190444

McMillen, H. L, T.Ticktin, and H. K. Springer. 2016. The future is behind us: traditional ecological knowledge and resilience over time on Hawai'i Island. Regional Environmental Change 17 (2):579-592. http://dx.doi.org/10.1007/s10113-016-1032-1

Melrose, J., R. Perroy, and S. Cares. 2016. Statewide agricultural land use baseline 2015. State Government of Hawaii, Honolulu, Hawaii, USA. [online] URL: https://hdoa.hawaii.gov/wpcontent/uploads/2016/02/StateAgLandUseBaseline2015.pdf

Millenium Ecosystem Assessment (MEA). 2005. Ecosystems and human well being: biodiversity synthesis. World Resources Institute, Washington, D.C., USA.

Mooney, H. 2016. Sustainability science: social-environmental systems (SES) research : how the field has developed and what we have learned for future efforts. Current Opinion in Environmental Sustainability 19:v-xii. http://dx.doi.org/10.1016/j.cosust.2016.05.002

Mooney, H., A. Larigauderie, M. Cesario, T. Elmquist, O. HoeghGuldberg, S. Lavorel, G. M. Mace, M. Palmer, R. Scholes, and T. Yahara. 2009. Biodiversity, climate change, and ecosystem services. Current Opinion in Environmental Sustainability 1(1):4654. http://dx.doi.org/10.1016/j.cosust.2009.07.006

Murphy, B. P., G. J. Williamson, and D. M. J. S. Bowman. 2011. Fire regimes: moving from a fuzzy concept to geographic entity. New Phytologist 192(2):316-318. http://dx.doi.org/10.1111/ j.1469-8137.2011.03893.x

Nader, G., Z. Henkin, E. Smith, R. Ingram, and N. Narvaez. 2007. Planned herbivory in the management of wildfire fuels: grazing is most effective at treating smaller diameter live fuels that can greatly impact the rate of spread of a fire along with the same height. Rangelands 29 (5):18-24. http://dx.doi.org/https://doi. org/10.2111/1551-501X(2007)29[18:PHITMO]2.0.CO;2
Pascual, U., P. Balvanera, S. Díaz, G. Pataki, E. Roth, M. Stenseke, R. T. Watson, E. Başak Dessane, M. Islar, E. Kelemen, V. Maris, M. Quaas, S. M. Subramanian, H. Wittmer, A. Adlan, S. E. Ahn, Y. S. Al-Hafedh, E. Amankwah, S. T. Asah, P. Berry, A. Bilgin, S. J. Breslow, C. Bullock, D. Cáceres, H. Daly-Hassen, E. Figueroa, C. D. Golden, E. Gómez-Baggethun, D. GonzálezJiménez, J. Houdet, H. Keune, R. Kumar, K. Ma, P. H. May, A. Mead, P. O'Farrell, R. Pandit, W. Pengue, R. Pichis-Madruga, F. Popa, S. Preston, D. Pacheco-Balanza, H. Saarikoski, B. B. Strassburg, M. van den Belt, M. Verma, F. Wickson, and N. Yagi. 2017. Valuing nature's contributions to people: the IPBES approach. Current Opinion in Environmental Sustainability 2627:7-16. http://dx.doi.org/10.1016/i.cosust.2016.12.006

Pausas, J. G., and J. E. Keeley. 2009. A burning story: the role of fire in the history of life. Bioscience (59):593-601. http://dx.doi. org/10.1525/bio.2009.59.7.10

Pierce, A. D., and E. Pickett. 2014. Building a spatial database of fire occurrence in Hawaii. Fire Management Today (74):37-42.

Preisler, H. K., D. R. Brillinger, R. E. Burgan, and J. W. Benoit. 2004. Probability based models for estimation of wildfire risk. International Journal of Wildland Fire 13:133-142. http://dx.doi. org/10.1071/WF02061

Raudsepp-Hearne, C., G. D. Peterson, and E. M. Bennett. 2010. Ecosystem service bundles for analyzing tradeoffs in diverse landscapes. Proceedings of the National Academy of Sciences United States of America 107(11):5242-5247. http://dx.doi. org/10.1073/pnas.0907284107

Raymond, C. M., J. Kenter, N. Turner, and K. Alexander. 2014. Comparing instrumental and deliberative paradigms underpinning the assessment of social values for cultural ecosystem services. Ecological Economics 107:145-156. http://dx.doi.org/10.1016/j. ecolecon.2014.07.033

Raynor, B. 1993. Documentation of indigenous Pacific agroforestry systems: a review of methodologies. Pages 69-74, General Technical Report 140, USDA Forest Service, Washington, D.C., USA.

Reddy, S. W., G. Guannel, R Griffin, J. Faries, T. Boucher, M. Thompson, J. Brenner, J. Bernhardt, G. Verutes, S. A. Wood, J. A. Silver, J. Toft, A. Rogers, A. Maas, A. Guerry, J. Molnar, and J. L. DiMuro. 2015. Evaluating the role of coastal habitats and sea-level rise in hurricane risk mitigation: an ecological economic assessment method and application to a business decision. Integrated Environmental Assessment and Management 12 (2):328-344. http://dx.doi.org/10.1002/ieam.1678

Ruckelshaus, M., E. McKenzie, H. Tallis, A. Guerry, G. Daily, P. Kareiva, S. Polasky, T. Ricketts, N. Bhagabati, S. A. Wood, and J. Bernhardt. 2015. Notes from the field: lessons learned from using ecosystem service approaches to inform real-world decisions. Ecological Economics 115:11-21. http://dx.doi. org/10.1016/j.ecolecon.2013.07.009

Runting, R. K., B. A. Bryan, L. E. Dee, F. J. F. Maseyk, L. Mandle, P. Hamel, K. A. Wilson, K. Yetka, H. P. Possingham, and J. R. Rhodes. 2016. Incorporating climate change into ecosystem service assessments and decisions: a review. Global Change Biology 23:28-41. http://dx.doi.org/10.1111/gcb.13457 
Sanford, T., P. C. Frumhoff, A. Luers, and J. Gulledge. 2014. The climate policy narrative for a dangerously warming world. Nature Climate Change 4(3):164-166. http://dx.doi.org/10.1038/nclimate2148

Thaman, R. 2014. Agrodeforestation and the loss of agrobiodiversity in the Pacific islands: a call for conservation. Pacific Conservation Biology 20(2):180-192. http://dx.doi. org/10.1071/PC140180

Tongco, M. D. C. 2007. Purposive sampling as a tool for informant selection. Ethnobotany Research and Applications 5:147-158. http://dx.doi.org/10.17348/era.5.0.147-158

Trauernicht, C., B. P. Murphy, T. E. Portner, and D. M. J. S. Bowman. 2012. Tree cover-fire interactions promote the persistence of a fire-sensitive conifer in a highly flammable savanna. Journal of Ecology 100(4):958-968. http://dx.doi. org/10.1111/j.1365-2745.2012.01970.X

Trauernicht, C., E. Pickett, C. P. Giardina, C. M. Litton, S. Cordell, and A. Beavers. 2015. The contemporary scale and context of wildfire in Hawai'i. Pacific Science 69(4):427-444. http://dx.doi.org/https://doi.org/10.2984/69.4.1

Vaughan, M. B., and P. M. Vitousek. 2013. Mahele: Sustaining communities through small-scale inshore fishery catch and sharing networks 1. Pacific Science 67(3):329-344. http://dx.doi. org/10.2984/67.3.3

Vorsino, A. E., L. B. Fortini, F. A. Amidon, S. E. Miller, J. D. Jacobi, J. P. Price, S. Ohukani, G. Iii, and G. A. Koob. 2014. Modeling Hawaiian ecosystem degradation due to invasive plants under current and future climates. PLoS One 9(5): e95427. http:// dx.doi.org/10.1371/journal.pone.0095427

Wada, C. A., L. L. Bremer, K. Burnett, C. Trauernicht, T. Giambelluca, L. Mandle, E. Parsons, C. Weil, N. Kurashima, and T. Ticktin. 2017. Estimating cost-effectiveness of Hawaiian dry forest restoration using spatial changes in water yield and landscape flammability under climate change. Pacific Science 71 (4):401-424 http://dx.doi.org/10.2984/71.4.2

White, A., and A. Martin. 2002. Who owns the world's forests? Forest tenure and public forest in transition. Forest Trends and Center for International Environmental Law, Washington, D.C., USA. [online] URL: http://www.forest-trends.org/documents/ files/doc 159.pdf

Winthrop, R. H. 2014. The strange case of cultural services: limits of the ecosystem services paradigm. Ecological Economics 108:208-214. http://dx.doi.org/10.1016/j.ecolecon.2014.10.005 


\section{APPENDIX 1}

\section{Methods}

Description of land-use scenarios - supporting information

We developed four land-use scenarios relevant for Ka'ūpūlehu and pasturelands in the broader Kona region based on discussions with the land-owner Kamehameha Schools and the local Ka'ūpūlehu community (Table A1.1).

In scenario 1-pasture - the area continues to be managed as pasture. This scenario was based on current land cover as defined by a commonly utilized land cover map in Hawai'i (LANDFIRE 2012).

In scenario 2-native forest restoration-all pasture within the ahupua'a is restored to native forest. Ka'ūpūlehu is home to one of the most successful community-based dry forest restoration projects with has spurred interest in forest restoration for multiple environmental, educational, and socio-cultural benefits (Cordell et al. 2008). Based on the current distribution of native forest in Ka'ūpūlehu, areas above 1000 m were restored to Hawai'i montane subalpine mesic forest; areas below $1000 \mathrm{~m}$ with greater than $750 \mathrm{~mm}$ mean annual rainfall (MAR) to Hawai'i lowland mesic forest; and areas below $1000 \mathrm{~m}$ with less than $750 \mathrm{~mm}$ MAR to Hawai'i lowland dry forest. We assumed restoration was not feasible below $350 \mathrm{~mm}$ based on current and historical distribution of forest in Hawai'i (NatureServe 2011).

Scenario 3-agroforestry-combines culturally and economically important native species and Polynesian introduced plants, and the more recently introduced agricultural tree crop, fig (Ficus carica). Agroforestry was historically practiced in the region and across Hawai' $i$, but there there is currently no traditional agroforestry practiced in or near Ka'ūpūlehu. Estimates of species richness and diversity were developed for a potential agroforestry scenario (see biodiversity methods below and table A12). These were based on expert knowledge of agroforestry systems practiced in similar environments elsewhere in the Pacific Islands, as well as what might be economically and environmentally viable in Ka'ūpūlehu currently. Figs were included as $10 \%$ of the management area, and we assumed they do not require irrigation beyond establishment (Andersen and Crocker 2016), a factor important to the landowner.

Finally, in scenario 4-coffee-pasture is converted to coffee within coffee's suitable climate zone. Coffee was limited to areas with mean annual temperatures greater than $15^{\circ} \mathrm{C}$ and less than $22.8^{\circ} \mathrm{C}$ (Bittenbender and Smith 2008) which constrained coffee to $13.6 \mathrm{~km}^{2}$ in the current climate and to $8.9 \mathrm{~km}^{2}$ under climate change (Table A1.1; Fig. 1 ). We assumed no import of water to meet irrigation needs, so negative water yield values 
in coffee areas indicate a water deficit in certain areas that needs to be supplied from groundwater (or catchment).

Table A1.1. Land-use scenarios developed for the current pasturelands of Ka'ūpūlehu, Hawai'i.

\begin{tabular}{|c|c|c|c|}
\hline Scenario & Description & $\begin{array}{l}\text { Management area } \\
\text { current climate }\end{array}$ & $\begin{array}{l}\text { Management area } \\
\text { future climate }\end{array}$ \\
\hline $\begin{array}{l}\text { Pasture } \\
\text { (current) }\end{array}$ & $\begin{array}{l}100 \% \text { pasture } \\
\text { (classified as } \\
\text { perennial } \\
\text { grassland); } \\
\text { primarily used for } \\
\text { grazing }\end{array}$ & $13.9 \mathrm{~km}^{2}$ & $13.9 \mathrm{~km}^{2}$ \\
\hline $\begin{array}{l}\text { Native } \\
\text { forest } \\
\text { restoration }\end{array}$ & $\begin{array}{l}\text { Restoration of } \\
\text { Hawai'i lowland dry } \\
\text { forest (Elevation } \\
<1000 \mathrm{~m} \text {; Mean } \\
\text { Annual Rainfall } \\
\text { (MAR) } 750 \mathrm{~mm} \text { ); } \\
\text { Hawai'i lowland } \\
\text { mesic forest } \\
\text { (Elevation <1000 } \\
\text { m; MAR >750mm); } \\
\text { Hawai'i montane } \\
\text { subalpine mesic } \\
\text { forest (Elevation } \\
>1000 \text { m) }\end{array}$ & $\begin{array}{l}13.9 \mathrm{~km}^{2} \text { (63\% } \\
\text { Hawai'i lowland dry } \\
\text { forest; 34\% Hawai'i } \\
\text { lowland mesic forest; } \\
4 \% \text { Hawai'i montane } \\
\text { subalpine mesic } \\
\text { forest) }\end{array}$ & $\begin{array}{l}13.9 \mathrm{~km}^{2} \text { (96\% Hawai'i } \\
\text { lowland dry forest; } 4 \% \\
\text { Hawai'i montane } \\
\text { subalpine mesic } \\
\text { forest) }\end{array}$ \\
\hline Agroforestry & $\begin{array}{l}\text { Restoration of } \\
\text { Hawaiian } \\
\text { agroforestry using } \\
\text { a mix of native and } \\
\text { non-native species; } \\
\text { includes } 10 \% \text { fig. }\end{array}$ & $13.9 \mathrm{~km}^{2}$ & $13.9 \mathrm{~km}^{2}$ \\
\hline Coffee & $\begin{array}{l}\text { Coffee (limited to } \\
\text { areas with mean } \\
\text { annual } \\
\text { temperature } 15- \\
22.8^{\circ} \mathrm{C} \text { ) }\end{array}$ & $13.6 \mathrm{~km}^{2}$ & $8.9 \mathrm{~km}^{2}$ \\
\hline
\end{tabular}

Methods to assess cultural ecosystem services: supporting information The cultural values work represents one site among three in a larger research project 
examining place-based and indigenous values on cultural ecosystem services across Hawai'i (Pascua et al. 2017). This research builds on a two-year collaborative research project on local knowledge and adaptation to change (Ka'ūpūlehu Community et al. 2014) where the community participants played a central role in determining methods, collecting and analyzing data, and creating an array of products. Methods included qualitative, in-depth interviews, focus groups, and workshops (see McMillen et al. (2016) for a full description of methods).

Our research in Ka'ūpūlehu followed culturally appropriate protocols for interacting with this community including thoughtfully engaging community elders and opening the workshop with a genealogical chant to demonstrate respect for both people and place (see Pascua et al. 2017). This process of building relationships, understanding, and trust between outside researchers and community members was fundamental to conducting our work in ways that respected and honored community perspectives and resonated with their priorities and goals.

Methods to assess groundwater recharge as a function of land-use and climate change scenarios: supporting information

Fog capture:

We employed a method developed by Engott (2011), where fog interception is calculated as:

$\mathrm{F}=\mathrm{P} \times \mathrm{FIR} \times \mathrm{FCE}$

Where $F=$ fog interception; $P=$ precipitation (as rainfall); $F I R=$ fog interception ratio; and $F C E=$ fog-catch efficiency.

Ka'ūpūlehu falls within fog interception zone 1 on Hawai'i Island (Engott 2011). This fog interception zone assigns a fog interception ratio between 0-1 (as the fraction of precipitation that represents fog interception in addition to mean annual precipitation) based on elevation.

Fog-catch efficiency (FCE) is defined by vegetation type where fog interception only occurs in forest (all types, including agroforestry) (=1) and shrubs (including coffee) (=.5). Grasslands, developed areas, and barren land covers are assigned an FCE of 0 (Engott 2011). The only modification made for climate change was changing rainfall as we did not have information on how FIR may change with climate change. FCE values were changed with land-use scenarios.

\section{Actual evapotranspiration:}

We estimated actual evapotranspiration (ET) under land-use and climate scenarios following (Wada et al. 2017) by creating linear regression equations with the annual latent heat flux equivalent (LE) of ET $\left(\mathrm{W} \mathrm{m}^{-2}\right)$ as a function of annual predictor variables: 1) air temperature; 2 ) net radiation; 3 ) relative humidity; 4) wind speed; 5) actual soil moisture; 6) leaf area index, canopy cover; and 7) vegetation height. We used a 
database of 288,007 points across the Hawaiian Islands based on ET modeling at the hourly time step (Giambelluca et al. 2014). These ET estimates were validated with eddy covariance flux towers and modeled ET was highly correlated with direct measurements $\left(r^{2}=0.91\right)$ and bias and random errors were very low $\left(\mathrm{MBE}=4 \mathrm{~W} \mathrm{m^{2 }}\right.$ and RMSE $=24 \mathrm{~W}$ $\mathrm{m}^{2}$ ) (Giambelluca et al. 2014). A simplified modeling approach allowed us to run multiple land-use and climate scenarios at the annual time step.

We first tested for collinearity and removed variables with a VIF > 5 (Zuur et al. 2009). We then incorporated spatial autocorrelation using the nlme package in $\mathrm{R}$ (Zuur et al. 2009) and selected the regression model with the lowest AIC value. We sub-setted larger land cover classes to 6463, the highest number of points in one land cover class that was able to run in $\mathrm{R}$ Studio without overwhelming the system. We maintained the points per island ratio in the subsets of larger land cover class. We used $<1200 \mathrm{~mm}$ rainfall subset for two of the land cover classes (Hawai'i lowland mesic forest and Hawai'i lowland dry forest), which did not work well with the state data set. This was considered appropriate given that rainfall was $<1200 \mathrm{~mm}$ in Ka'ūpūlehu.

LE values were used to obtain ET in water units $(\mathrm{mm})$ by the equation:

$$
n / \lambda * \rho_{w}
$$

Where the $n=$ number of seconds in the relevant time period, $\lambda=$ the latent heat of vaporization of water $\left(\mathrm{J} \mathrm{kg}^{-1}\right)$, and $\rho_{w}=$ density of water $\left(\mathrm{kg} \mathrm{m}^{-3}\right)$ at the relevant temperature (Giambelluca et al., 2014).

\section{ET model comparison with full ET model}

We compared ET as estimated from the regression model to the full model estimates from Giambelluca et al. (2014) for each land cover type. Adjusted $R^{2}$ values were as follows: introduced perennial grassland (pasture): 0.91; Hawai' $i$ subalpine mesic forest: 0.92; Hawai'i lowland mesic forest: 0.63; Hawai'i lowland dry forest: 0.66; coffee: 0.89; and introduced deciduous shrubland (used for fig): 0.99 . Because adjusted $R^{2}$ does not account for the effects of spatial autocorrelation that we accounted for in the regression models, it is an imperfect, and likely conservative, measure of model fit. Within the Ka'ūpūlehu ahupua'a, the difference between the full model and regression model was $<5 \%$ across all land cover types present.

Land-use and climate change scenario calculations:

Land-use changes were first accounted for by reassigning the appropriate regression equation for the new land cover. Coffee, pasture, and native forest were all modeled using the respective land cover classes in LANDFIRE (2012). We modeled agroforestry as $90 \%$ native forest cover - with adjusted leaf area index and vegetation heights (see below) - and as $10 \%$ introduced deciduous shrubland, a land cover class with a similar 
stomatal conductance as fig (Giambelluca et al. 2014; González-Rodríguez and Peters 2010).

We changed annual vegetation height, LAI, and canopy cover to the median value for the given land cover in the Kona region as we did not find a relationship between these variables and rainfall. The $90 \%$ native agroforest LAI and canopy cover were calculated as an average of values for mixed agriculture and native forest. Vegetation height was calculated as . $7 *$ median height of forest $+.3 *$ median height of mixed agriculture. This was based on the assumption that agroforestry would have $70 \%$ the density of trees. For the $10 \%$ fig, we used literature values for average height (Andersen and Crocker 2016) and used median values for canopy cover of another orchard crop (macadamia) for which spatial data on LAI and canopy cover was available.

To capture the likely impacts of land-use and climate change on mean annual net radiation, we calculated annual net radiation as a function of rainfall and land cover class (divided into forest, shrub, grass, barren, and developed). We included spatial autocorrelation in the model to obtain the best fit model (Zuur et al. 2009). We used a Kona subset for net radiation predictions. To maintain the spatial variability, we adjusted net radiation for future climates and changes in land use using the marginal difference between modeled net radiation (as a function of precipitation and land cover type). The best model included spatial autocorrelation and did not include an interaction of land use and rainfall.

Following Giambelluca et al. (2014), we did not change available soil moisture with landuse change, with the exception of transitions to irrigated land covers (coffee). For coffee, we used the Kona area median 0.82 available soil moisture for coffee land cover and assumed irrigation to meet ET demand. To adjust available soil moisture under climate change we followed Giambelluca et al. (2014)'s method where:

$$
y=0.182 * \ln (x)+0.2632
$$

and where $y=$ soil moisture (percent) and $x=$ average of current and previous month mean rainfall ( $\mathrm{mm} /$ day). We used statically downscaled estimates for wet and dry season rainfall ( 6 months wet season and 6 months dry season) to adapt the available soil moisture layer (Elison Timm et al. 2014) ${ }^{1}$. We followed IPCC RCP 8.5 mid-century projections by increasing temperature 1.4 degrees C across the study area (IPCC 2014). All scenario calculations were done in ArcMap raster calculator.

Uncertainty associated with groundwater recharge estimates:

We estimated the error of the modeled ET as the difference between the full ET model (Giambelluca et al. 2014) and the simplified regression model (as described above) (Wada et al. 2017). To do so, we computed the mean absolute and mean percent error

${ }^{1} 2016$ corrected projections were used. 
(along with standard deviations) between the full model and the simplified regression model for each land cover class (at a 250 m pixel scale) within Ka'ūpūlehu. We used the following equations:

1. Mean absolute error for given land class=

$$
\frac{\sum_{i \in K}(E T 1-E T 2)}{n}
$$

where $i=$ a pixel in land class $k$; $n=$ number of pixels in land class $k ; E T 1=a c t u a l$ evaporation as calculated by regression model; and $E T 2=$ actual evapotranspiration as calculated by full model.

2. Mean percent error for given land class $=$

$$
\frac{\sum_{i \in K} \frac{(E T 1-E T 2)}{E T 2} * 100}{n}
$$

where $i=$ a pixel in land class $k$; $n=$ number of pixels in land class $k ; E T 1=a c t u a l$ evaporation as calculated by regression model; and $E T 2=$ actual evapotranspiration as calculated by full model.

Where there were $n \geq 30$ pixels of a given land cover within the study ahupua'a, we used only pixels within the ahupua'a for comparison. However, in some cases land covers were not present in the ahupua'a $250 \mathrm{~m}$ map (but were present in the higher resolution $30 \mathrm{~m}$ map) or were in a scenario (e.g. coffee), but not in the current land cover map.

To characterize the uncertainty of land-use scenarios, we adjusted the ET estimates calculated using the regression equations as follows:

\section{Adjusted ET =}

$$
E T 1 /(1-F 1)
$$

Where $E T 1=$ actual evapotranspiration as calculated by regression model and $F 1=$ fraction underestimate of regression model compared to full model.

Error estimates are reported as one standard deviation around the adjusted AET in terms of percent difference between the regression model and the full model.

We used the following equations to calculate the change between scenarios:

4. Mean difference between scenarios = 


$$
\text { ET1adj }-E T 2 a d j
$$

Where ET1adj= bias adjusted AET scenario 1 and ET2 adj=bias adjusted AET scenario 2.

5. SD of difference $=$

$$
S Q R T\left(S D E T 1 a d j^{2}+S D E T 2 a d j^{2}\right)
$$

Where SDET1adj = standard deviation of bias adjusted AET scenario 1 and SDET2adj = standard deviation of bias adjusted AET scenario 2.

We used the following equations to translate this into percent change:

6. Percent change between scenarios $=$

$$
\frac{E T 1 a d j-E T 2 a d j}{E T 1} * 100
$$

7. SD percent change $=$

$$
\frac{S D(E T 1 a d j-E T 2 a d j)}{E T 1} * 100
$$

Scenarios were considered meaningfully or significantly different from each other when the difference in ET was greater than the SD of the difference.

Methods to assess landscape flammability as a function of land-use and climate change scenarios: supporting information

We used a 20-year data set of burned area perimeters collected for the NW quadrant of Hawai'i Island by the Hawai'i Wildfire Management Organization to classify annual samples of random points across the landscape $(\mathrm{N}=150,000)$ as burnt or unburnt in a GIS. The dataset included the spatial extent of 91 fires ranging from 1 ha to $>10,000$ ha for the $3,000 \mathrm{~km}^{2}$ landscape comprising the NW quadrant of Hawai'i Island. This binomial response was used to model the annual probability of fire occurrence per pixel as a function of (i) mean annual rainfall, (ii) mean annual temperature, (iii) land cover (Forest, Shrubland, Grassland, Agricultural, Developed, and Other from the 30m resolution 2012 LANDFIRE product), (iv) ignition density (derived from point-based wildfire records; (Pierce and Pickett 2014)), (v) aspect, and (vi) the annual rainfall anomaly (difference between annual and mean annual rainfall for the sample year) using generalized additive models (GAM; e.g. Brillinger et al. 2006). We fit models using all possible combinations of predictor variables, including an interaction between rainfall land cover, an interaction between rainfall anomaly and land cover, and sample 
year as a random effect (Brillinger et al., 2006) and ranked these against the null model using Akaike's Information Criterion (AICc; Burnham and Anderson, 2013)

We used the top-ranked model (the global model; Akaike Weight >0.99; Explained Deviance $=25.9 \%$ ) and the Raster package in R (Hijmans and Van Etten, 2013) to predict the annual probability of fire occurrence across the Kā'ūpulehu watershed under current conditions (pasture), forest restoration, coffee and future changes in mean annual rainfall and mean annual temperature under the RCP 8.5 mid century scenario. The annual rainfall anomaly was set at zero for all predictions. The use of randomized, annual, point-based samples within $30 \times 30 \mathrm{~m}$ pixels (i.e. the resolution of land cover products) resulted in a model output that equates to the annual probability of fire occurrence per pixel. However, as the model response was derived from the annual extent of area burned over 20 years in the region, the per-pixel fire probabilities are best interpreted as the type of fire regime (e.g., high vs. low frequency) supported by the landscape and climatic features at each pixel, which we refer to as "landscape flammability." We explicitly excluded a spatial term in the model so that predicted fire occurrence probabilities were derived solely from landscape features and not weighted towards previously burned areas.

The predictors outlined above were selected based on data availability and the objective of assessing of how landscape features, and changes in those features, namely, land cover and climate, influence potential fire occurrence within the study area at Ka'ūpūlehu. Fire occurrence in Hawai' $i$ is also driven by shorter-term temporal variability in weather conditions and human-caused ignitions, which were not captured in the model. The high uncertainty of these predictors and the lack of adequate temporal resolution in the annual fire history constrained the explanatory power of our best ranked model (see above). However, the predictors we used do capture the fundamental drivers of ecosystem fire occurrence - climate, vegetation, ignition source, and topography (Pausas and Keeley 2009).

Methods to estimate biodiversity conservation values as a function of land use scenarios: supporting information

To assess biodiversity conservation value, we measured plant species richness and cover at field sites representative of the Ka'ūpūlehu scenarios. We focused only on plants, since with the exception of one species of bat, there are no native mammals in Hawai'i, nor native reptiles or amphibians; and over the elevation range of our study area, there are very few native bird species. We placed randomly located $10 \times 50 \mathrm{~m}$ transects in pasture, restored native forest, and coffee monoculture land covers. Three transects were established in each of the forest and pasture land covers and were sufficient to capture most of the species richness of those land-uses based on species accumulation curves. Similarly, one transect was established in the coffee monoculture due to the homogeneity of the vegetation in this land use. 
The restored native forest transects were established just across the border of an adjacent ahupua'a (Pu'u Wā'awā'a), due to the ability for us to easily monitor there. In terms of species composition, these were representative of the small area of restored native forest within Ka'ūpūlehu. Although the latter has been restored with more species, especially in the understory. Therefore our species richness estimates for the restored native forest scenario are likely underestimates. Within each transect, we established five adjacent $10 \mathrm{~m} \times 10 \mathrm{~m}$ plots. In each $10 \mathrm{~m} \times 10 \mathrm{~m}$ plot we identified and measured the height and diameter for all trees $>1.34 \mathrm{~m}$ tall and $>1 \mathrm{~cm} \mathrm{dbh}$. We also visually estimated percent canopy cover of tree species. We randomly selected a corner quadrat within each $10 \mathrm{~m} \times 10 \mathrm{~m}$ plot to establish a nested $5 \mathrm{~m} \times 5 \mathrm{~m}$ subplot. Within each $5 \mathrm{~m} \times 5 \mathrm{~m}$ subplot we recorded the identity of all understory herbaceous and woody plant species ( $<1.34 \mathrm{~m}$ tall), and visually estimated percent cover by plant species, bare soil, rock, and dead wood. Samples were collected for all species not identified in the field. We identified a total of 56 species in the transects.

Given that there is currently no traditional agroforestry practiced in or near Ka'ūpūlehu, estimates of species richness and cover were developed for a potential agroforestry scenario based on expert knowledge of agroforestry systems practiced historically in Ka'ūpūlehu and those currently in practiced in similar environments elsewhere in the Pacific Islands. We assumed that the richness and cover of understory non-native species would be the same in the agroforest as the restored forest, since both are managed to remove these weedy species but it is impossible to eliminate them.

We used Bootstrap estimates to estimate species richness for the pasture, coffee and restored forest sites. All analyses were done using the $\mathrm{R}$ package Vegan (Oksanen et al. 2013). Since the agroforest scenario was not based on empirical data, we did not generate error estimates for any of the richness or cover values we assigned.

We categorized species as invasive species based on the Hawai'i state list of noxious weeds and those categorized as dominant invaders by the South Pacific Regional Environment Programme (Shirley 2000).

Table A1.2. Species composition for Agroforestry scenario. The species list was developed based on the composition of Hawaiian agroforestry systems historically practiced in the region, and the abundance of native species in the study site that are currently culturally and economically important. It includes Fig, an economically important introduced species with a growing market, appropriate for the climatic zone. Threatened/Endangered species are based on U.S. Fish and Wildlife Service listed species believed to or known to occur in Hawai'i (U.S. Fish and Wildlife Service 2015).

\begin{tabular}{|l|l|l|l|}
\hline Common Name & Scientific Name & Native Status & $\begin{array}{l}\text { Threatened or } \\
\text { Endangered }\end{array}$ \\
\hline
\end{tabular}

Root/Tuber/Ground Cover 


\begin{tabular}{|c|c|c|c|}
\hline ko'oko'olau & $\begin{array}{l}\text { Bidens micrantha } \\
\text { Gaudich. }\end{array}$ & Endemic & $\begin{array}{l}\text { Yes (certain varieties } \\
\text { are endangered) }\end{array}$ \\
\hline Palapalai & $\begin{array}{l}\text { Microlepia strigosa } \\
\text { (Thunb.) C. Presl }\end{array}$ & Indigenous & No \\
\hline $\begin{array}{l}\text { 'uala (sweet } \\
\text { potato) }\end{array}$ & $\begin{array}{l}\text { Ipomoea batatas (L.) } \\
\text { Lam. }\end{array}$ & $\begin{array}{l}\text { Polynesian } \\
\text { introduced }\end{array}$ & No \\
\hline ‘uhi (yam) & Dioscorea alata $L$. & $\begin{array}{l}\text { Polynesian } \\
\text { introduced }\end{array}$ & No \\
\hline olena (tumeric) & Curcuma longa $L$. & $\begin{array}{l}\text { Polynesian } \\
\text { introduced }\end{array}$ & No \\
\hline \multicolumn{4}{|l|}{ Shrubs } \\
\hline Māmaki & $\begin{array}{l}\text { Pipturus albidus } \\
\text { (Hook. \& Arn.) A. } \\
\text { Gray }\end{array}$ & Endemic & No \\
\hline Halapepe & $\begin{array}{l}\text { Chrysodracon } \\
\text { hawaiiensis (O. Deg. } \\
\text { \& I. Deg.) P.-L. Lu \& } \\
\text { Morden }\end{array}$ & Endemic & Yes \\
\hline 'a'ali'i & $\begin{array}{l}\text { Dodonea viscosa } \\
\text { Jacq. }\end{array}$ & Indigenous & No \\
\hline kō (sugarcane) & $\begin{array}{l}\text { Saccharum } \\
\text { officinarum } L .\end{array}$ & $\begin{array}{l}\text { Polynesian } \\
\text { introduced }\end{array}$ & No \\
\hline \multicolumn{4}{|l|}{ Overstory } \\
\hline Lama & $\begin{array}{l}\text { Diospyros } \\
\text { sandwichensis ( } A \text {. } \\
D C .) \text { Fosberg }\end{array}$ & Endemic & No \\
\hline ‘ōhi'a & $\begin{array}{l}\text { Metrosideros } \\
\text { polymorpha Gaudich. }\end{array}$ & Endemic & No \\
\hline $\begin{array}{l}\text { 'iliahi } \\
\text { (sandalwood) }\end{array}$ & $\begin{array}{l}\text { Santalum } \\
\text { paniculatum Hook. \& } \\
\text { Arn. }\end{array}$ & Endemic & No \\
\hline Wiliwili & $\begin{array}{l}\text { Erythrina sanwicensis } \\
\text { O. Deg. }\end{array}$ & Endemic & No \\
\hline Kauila & $\begin{array}{l}\text { Columnbrina } \\
\text { oppositifolia Brongn. } \\
\text { Ex H. Mann }\end{array}$ & Endemic & Yes \\
\hline Lama & $\begin{array}{l}\text { Diospyros } \\
\text { sandwichensis (A. } \\
D C .) \text { Fosberg }\end{array}$ & Endemic & No \\
\hline Uhiuhi & $\begin{array}{l}\text { Caesalpinia } \\
\text { kavaiensis H. Mann }\end{array}$ & Endemic & Yes \\
\hline
\end{tabular}




\begin{tabular}{|l|l|l|l|}
\hline 'ulu (breadfruit) & $\begin{array}{l}\text { Artocarpus altilis } \\
\text { (Parkinson) Fosberg }\end{array}$ & $\begin{array}{l}\text { Polynesian } \\
\text { introduced }\end{array}$ & No \\
\hline $\begin{array}{l}\text { Kukui } \\
\text { (candlenut) }\end{array}$ & $\begin{array}{l}\text { Aleurites moluccana } \\
\text { (L.) Willd. }\end{array}$ & $\begin{array}{l}\text { Polynesian } \\
\text { introduced }\end{array}$ & No \\
\hline Fig & Ficus carica L. & Introduced & No \\
\hline Climbers & $\begin{array}{l}\text { Freycinetia arborea } \\
\text { Gaudich. }\end{array}$ & Indigneous & No \\
\hline 'ie'ie & & & \\
\hline
\end{tabular}

Methods to estimate economic returns to landowners as a function of land-use scenarios: supporting information

Table A1.3. Parameter descriptions and values for pasture/cattle ranching scenario

\begin{tabular}{lll}
\hline Description & Value & Units \\
\hline Total area classified as pasture & 3,345 & Acres \\
Cattle and calves sold statewide in 2012 & 56,119 & Heads \\
Average value per cow sold in 2012 & 699.18 & 2015 dollars \\
Cattle per acre in 2012 & 0.17 & Heads/acre \\
Annual cow maintenance cost in 2009 & 278 & 2015 dollars/cow/year \\
Export (shipping) cost per acre in 2012 & 7.55 & 2015 dollars/acre \\
Total cost per acre & 53.72 & 2015 dollars/acre \\
Total revenue per acre & 116.25 & 2015 dollars/acre \\
Net revenue per acre & 62.53 & 2015 dollars/acre \\
\hline
\end{tabular}

Table A1.4. Annual revenue and costs for pasture/cattle ranching scenario

\begin{tabular}{lrrrr}
\hline Year & Cumulative Acres & \multicolumn{2}{c}{$\begin{array}{l}\text { Cumulative } \\
\text { Cattle Added }\end{array}$} & \multicolumn{2}{c}{$\begin{array}{l}\text { Annual Cost } \\
\text { (Millions) }\end{array}$} & \multicolumn{2}{l}{$\begin{array}{l}\text { Annual Revenue } \\
\text { (Millions) }\end{array}$} \\
\hline 2025 & 3,435 & 571 & $\$ 0.17$ & $\$ 0.19$ \\
2035 & 3,435 & 571 & $\$ 0.17$ & $\$ 0.19$ \\
2045 & 3,435 & 571 & $\$ 0.17$ & $\$ 0.19$ \\
2055 & 3,435 & 571 & $\$ 0.17$ & $\$ 0.19$ \\
2065 & 3,435 & 571 & $\$ 0.17$ & $\$ 0.19$ \\
\hline
\end{tabular}

Table A1.5. Parameter descriptions and values for native forest restoration scenario

\begin{tabular}{lll}
\hline Description & Value & Units \\
\hline Wage rate & 22 & 2015 dollars/hour \\
Total transformed area & 3,435 & Acres \\
Perimeter (square) of Fence 1 & 36,039 & Feet \\
Perimeter (square) of Fence 2 & 36,039 & Feet
\end{tabular}


Fence material cost per foot ${ }^{\mathrm{a}}$

Material cost for each fence

Fence labor cost per foot ${ }^{a}$

Labor cost for each fence

Per-acre wire replacement cost ${ }^{b}$

Wire replacement cost for each fence

Annual ungulate control cost ${ }^{a}$

Outplanting density ${ }^{c}$

Outplanting rate ${ }^{c}$

Cost per plant ${ }^{c}$

Total outplanting cost per acre

Weeding effort per acre ${ }^{d}$

Weeding cost per acre
6.94

250,024

11.24

405,224

100

186,350

169,409

31

2.6

2.34

340

104.4

2,297
2015 dollars/foot

2015 dollars

2015 dollars/foot

2015 dollars

2015 dollars/acre

2015 dollars

2015 dollars

Plants/acre

Plants/hour

2015 dollars/plant

2015 dollars/acre

Hours/acre

2015 dollars/acre

${ }^{a}$ Based on Henahena cost estimates (personal communication, Elliott Parsons)

${ }^{b}$ Based on Kaiholena cost estimates (personal communication, Shalan Crysdale)

'Based on Puu Waawaa project data (personal communication, Elliott Parsons)

${ }^{d}$ Based on Haena cost assumptions (personal communication, Kawika Winters)

Table A1.6. Annual revenue and costs for native forest restoration scenario

\begin{tabular}{|c|c|c|c|}
\hline Year & $\begin{array}{l}\text { Cumulative Acres } \\
\text { Converted }\end{array}$ & $\begin{array}{l}\text { Cumulative Plants } \\
\text { Added }\end{array}$ & Annual Cost (Millions) \\
\hline 2025 & 687 & 21,614 & $\$ 0.18$ \\
\hline 2035 & 1,374 & 43,227 & $\$ 0.18$ \\
\hline 2045 & 2,061 & 64,841 & $\$ 0.56$ \\
\hline 2055 & 2,748 & 86,454 & $\$ 0.18$ \\
\hline 2065 & 3,435 & 108,068 & $\$ 0.18$ \\
\hline
\end{tabular}

Table A1.7. Parameter descriptions and values for coffee scenarios

\begin{tabular}{lll}
\hline Description & Value & Units \\
\hline Wage rate & 22 & 2015 dollars/hour \\
Total area converted to coffee & 3,361 & Acres \\
Planting density* & 615 & Plants/acre \\
Cherry yield per plant** & 14.3 & Pounds/plant/year \\
Farm price*** & 4.19 & 2015 dollars/pound \\
Cost per plant** & 40.43 & 2015 dollars/plant/year \\
\hline *Based on Kamehameha Schools trial density (8,000 trees/13 acres) \\
**http://www.ctahr.hawaii.edu/oc/freepubs/pdf/ab-11.pdf \\
***http://www.nass.usda.gov/Statistics_by_State/Hawaii/Publications/Sugarcane_and_ \\
Specialty_Crops/201508coffee.pdf
\end{tabular}

Table A1.8. Annual revenue and costs for coffee scenario (current climate) 


\begin{tabular}{|c|c|c|c|c|}
\hline Year & $\begin{array}{l}\text { Cumulative Acres } \\
\text { Converted }\end{array}$ & $\begin{array}{l}\text { Cumulative Plants } \\
\text { Added }\end{array}$ & $\begin{array}{l}\text { Annual Cost } \\
\text { (Millions) }\end{array}$ & $\begin{array}{l}\text { Annual Revenue } \\
\text { (Millions) }\end{array}$ \\
\hline 2025 & 672 & 413,662 & $\$ 16.7$ & $\$ 24.7$ \\
\hline 2035 & 1,344 & 827,323 & $\$ 33.5$ & $\$ 49.5$ \\
\hline 2045 & 2,017 & $1,240,985$ & $\$ 50.2$ & $\$ 74.3$ \\
\hline 2055 & 2,689 & $1,654,646$ & $\$ 66.9$ & $\$ 99.1$ \\
\hline 2065 & 3,361 & $2,068,308$ & $\$ 83.6$ & $\$ 123.9$ \\
\hline
\end{tabular}

Table A1.9. Annual revenue and costs for coffee scenario (RCP 8.5 mid century)

\begin{tabular}{|c|c|c|c|c|}
\hline Year & $\begin{array}{l}\text { Cumulative Acres } \\
\text { Converted }\end{array}$ & $\begin{array}{l}\text { Cumulative Plants } \\
\text { Added }\end{array}$ & $\begin{array}{l}\text { Annual Cost } \\
\text { (Millions) }\end{array}$ & $\begin{array}{l}\text { Annual Revenue } \\
\text { (Millions) }\end{array}$ \\
\hline 2025 & 440 & 270,646 & $\$ 10.9$ & $\$ 16.2$ \\
\hline 2035 & 880 & 541,292 & $\$ 21.9$ & $\$ 32.4$ \\
\hline 2045 & 1,319 & 811,938 & $\$ 32.8$ & $\$ 48.6$ \\
\hline 2055 & 1,759 & $1,082,585$ & $\$ 43.8$ & $\$ 64.8$ \\
\hline 2065 & 2,199 & $1,353,231$ & $\$ 54.7$ & $\$ 81.0$ \\
\hline
\end{tabular}

Table A1.10. Parameter descriptions and values for Hawaiian agroforestry scenario

\begin{tabular}{|c|c|c|}
\hline Description & Value & Units \\
\hline \multicolumn{3}{|c|}{ Figs (10\% of total converted area) } \\
\hline Total transformed area & 343 & Acres \\
\hline Wage & 22 & 2015 dollars/hour \\
\hline Planting density ${ }^{a}$ & 155 & Plants/acre \\
\hline Variable cost per acre ${ }^{b}$ & 107,199 & 2015 dollars/acre/year \\
\hline Cost per plant ${ }^{\mathrm{c}}$ & 20 & 2015 dollars/plant \\
\hline Yield per plant ${ }^{b}$ & 788 & Pounds/plant/year \\
\hline Market price $^{b}$ & 3.84 & 2015 dollars/pound \\
\hline \multicolumn{3}{|c|}{ Sweet Potatoes (50\% of total converted area) } \\
\hline Total transformed area & 1,546 & Acres \\
\hline Yield per acre $^{d}$ & 8,300 & Pounds/acre \\
\hline Farm value per acre ${ }^{d}$ & 6,905 & 2015 dollars/acre \\
\hline Production cost per acre ${ }^{\mathrm{e}}$ & 5,312 & 2015 dollars/acre \\
\hline \multicolumn{3}{|c|}{ Native Forest (15\% of total converted area) } \\
\hline \multicolumn{3}{|c|}{ See S2 Table 4} \\
\hline \multicolumn{3}{|c|}{ Native Tea (10\% of total converted area) } \\
\hline Total transformed area & 343 & Acres \\
\hline Planting density ${ }^{f}$ & 3,000 & Plants/acre \\
\hline Cost per acre ${ }^{f}$ & 96,678 & 2015 dollars/acre/year \\
\hline Yield per acre $^{f}$ & 750 & Pounds/acre/year \\
\hline Market price for tea ${ }^{g}$ & 200 & 2015 dollars/pound \\
\hline
\end{tabular}


Koa (15\% of total converted area)

Total transformed area

Establishment cost per acre ${ }^{h}$

Current price ${ }^{\mathrm{i}}$

Price growth rate ${ }^{i}$

Acres harvested starting at year 35

Yield per acre ${ }^{\mathrm{h}}$

${ }^{a}$ U.C. Cooperative Extension (1994)

${ }^{\mathrm{b}} \mathrm{CTAHR}$ (2007) - adjusted for inflation

chttp://plantithawaii.com/price-list/

dhttp://www.nass.usda.gov/Statistics_by_State/Hawaii/Publications/Vegetables/20150

1vegrv.pdf

ehttp://www.extento.hawaii.edu/kbase/reports/sweetpot_prod.htm

f Nakamoto et al. (2011)

ghttp://www.mama-kii.com/collections/all

hIdol et al. (2007):

http://www.hawaiiforestinstitute.org/documents/journal_sept2007.pdf

'Goldstein et al. (2006): http://www.pnas.org/content/103/26/10140.abstract

Table A1.11. Annual revenue and costs for Hawaiian agroforestry scenario

\begin{tabular}{lrrr}
\hline Year & $\begin{array}{l}\text { Cumulative Acres } \\
\text { Converted }\end{array}$ & $\begin{array}{l}\text { Annual Cost } \\
\text { (Millions) }\end{array}$ & $\begin{array}{l}\text { Annual Revenue } \\
\text { (Millions) }\end{array}$ \\
\hline 2025 & 1,099 & $\$ 15.9$ & $\$ 34.3$ \\
2035 & 1,683 & $\$ 31.7$ & $\$ 79.2$ \\
2045 & 2,266 & $\$ 47.6$ & $\$ 124.1$ \\
2055 & 2,850 & $\$ 63.4$ & $\$ 171.6$ \\
2065 & 3,434 & $\$ 79.2$ & $\$ 213.9$ \\
\hline
\end{tabular}

Acres

2015 dollars/acre

2015 Dollars/board foot

Acres/year

Board feet/acre
2,249

0.01

50

8,500

$\begin{array}{ll}515 & \text { Acres } \\ 2,249 & 2015 \text { dollars/acre } \\ 4.11 & 2015 \text { Dollars/board foot } \\ 0.01 & \\ 50 & \text { Acres/year } \\ 8,500 & \text { Board feet/acre }\end{array}$




\section{Results}

Groundwater recharge results: supporting information

Table A1.12. Mean Annual Rainfall (MAR), fog interception, evapotranspiration, and groundwater recharge in the study area in millions of liters per year (MLPY). Letters indicate significant differences in AET and groundwater recharge among land uses within each climate scenario.

\begin{tabular}{|c|c|c|c|c|c|}
\hline Scenario & Area & AET (MLPY) & MAR (MLPY) & $\begin{array}{l}\text { Fog } \\
\text { interception } \\
\text { (MLPY) } \\
\end{array}$ & $\begin{array}{l}\text { Groundwater } \\
\text { recharge } \\
\text { (MLPY) }\end{array}$ \\
\hline \multicolumn{6}{|c|}{ Current climate } \\
\hline Pasture & $13.9 \mathrm{~km}^{2}$ & $5829(313)^{c}$ & 9350 & 0 & $3521(313)^{a}$ \\
\hline Native forest & $13.9 \mathrm{~km}^{2}$ & $6213(315)^{b c}$ & 9350 & 214 & $3351(315)^{a b}$ \\
\hline Agroforestry & $13.9 \mathrm{~km}^{2}$ & $6715(409)^{b}$ & 9350 & 214 & $2850(409)^{b}$ \\
\hline Coffee & $\begin{array}{r}13.7 \mathrm{~km}^{2} \\
\text { coffee/0.2 } \\
\mathrm{km}^{2} \text { pasture }\end{array}$ & $12,293(332)^{a}$ & 9350 & 93 & $-2850(332)^{\mathrm{C}}$ \\
\hline \multicolumn{6}{|c|}{ Future climate } \\
\hline Pasture & $13.9 \mathrm{~km}^{2}$ & $5313(285)^{b c}$ & 6478 & 0 & $1164(285)^{\mathrm{bc}}$ \\
\hline Native forest & $13.9 \mathrm{~km}^{2}$ & $4988(179)^{c}$ & 6478 & 163 & $1652(179)^{a}$ \\
\hline Agroforestry & $13.9 \mathrm{~km}^{2}$ & $5663(278)^{b}$ & 6478 & 163 & $978(278)^{\mathrm{C}}$ \\
\hline Coffee & $\begin{array}{r}8.9 \mathrm{~km}^{2} \\
\text { coffee } / 5 \\
\mathrm{~km}^{2} \text { pasture }\end{array}$ & $9747(263)^{a}$ & 6478 & 81 & $-3188(263)^{d}$ \\
\hline
\end{tabular}

Landscape flammability results: supporting information

Fig A1.1. The annual area burned for the NW quadrant of Hawaii Island from 1992 to 2011. 


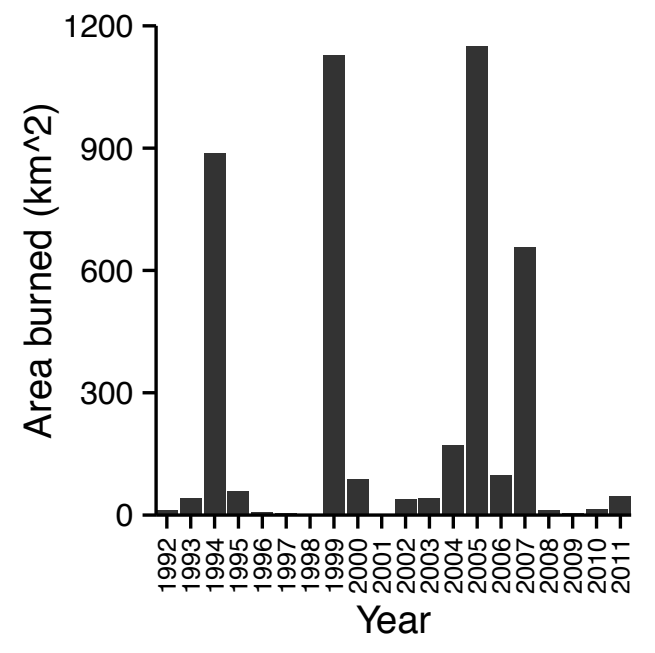


Fig A1.2. The probability of fire occurrence for grasslands, shrublands, and forest. Points indicate actual probabilities calculated as the proportion and standard deviation (error bars) of area burned binned across the rainfall gradient. Solid lines indicate model predictions and dashed lines indicate the upper and lower $95 \%$ confidence intervals. Rug plots below illustrate the distribution of mean annual rainfall across the Kaupulehu watershed under current conditions (black rug) and under the RCP 8.5 climate change scenario (gray rug).

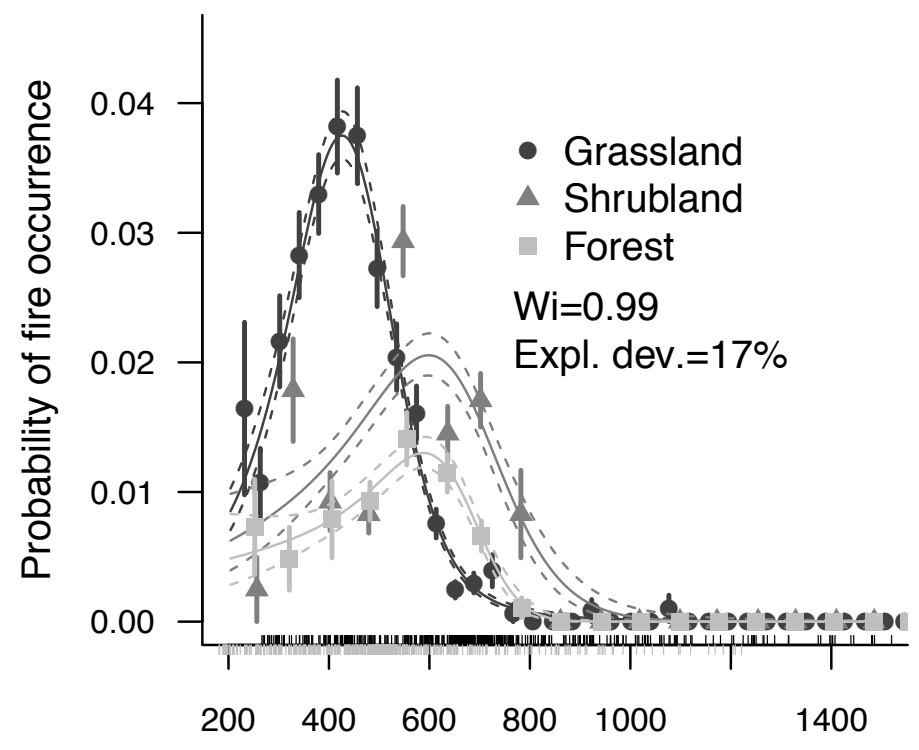

Mean annual rainfall $(\mathrm{mm})$

Biodiversity value results: supporting information

Table A1.13. Species richness and vegetation cover by land-use scenario in Ka'ūpūlehu Hawai'i. Values represent means \pm 1 SE. The category "non-native" includes both introduced and invasive species. Species richness was estimated using a Bootstrap estimator, numbers in parentheses represent actual species counts from the transects.

\begin{tabular}{|c|c|c|c|c|c|c|c|c|}
\hline $\begin{array}{c}\text { Land use } \\
\text { Scenario }\end{array}$ & \multicolumn{4}{|c|}{ Species Richness } & \multicolumn{3}{c|}{ Vegetation Cover (\%) } \\
\hline & \multicolumn{2}{|c|}{ Canopy } & \multicolumn{2}{|c|}{ Understory } & \multicolumn{2}{c|}{ Canopy } & \multicolumn{2}{c|}{ Understory } \\
\hline & Native & $\begin{array}{c}\text { Non- } \\
\text { native }\end{array}$ & Native & $\begin{array}{c}\text { Non- } \\
\text { native }\end{array}$ & Native & $\begin{array}{c}\text { Invasiv } \\
\mathrm{e}\end{array}$ & Native & Invasive \\
\hline Pasture & 0 & $\begin{array}{c}4.2 \pm 1.9 \\
(4)\end{array}$ & 0 & $\begin{array}{c}28.9 \pm 6 \\
(22)\end{array}$ & 0 & $\begin{array}{c}6.7 \pm 3 . \\
9\end{array}$ & 0 & $\begin{array}{c}87.6 \pm .3 . \\
6\end{array}$ \\
\hline Coffee & 0 & 1 & 0 & $\begin{array}{c}17.7 \pm 2 \\
(15)\end{array}$ & 0 & 0 & 0 & $0.8 \pm 0.4$ \\
\hline
\end{tabular}




\begin{tabular}{|c|c|c|c|c|c|c|c|c|}
\hline $\begin{array}{c}\text { Agrofores } \\
\mathrm{t}\end{array}$ & 10 & 3 & 3 & $20+$ & 16 & 0 & 10 & 6 \\
\hline Forest & $\begin{array}{c}16.7 \pm 1 \\
.3(14)\end{array}$ & 0 & $\begin{array}{c}7.1 \pm 1 . \\
1(6)\end{array}$ & $\begin{array}{c}17.9 \pm 1 . \\
4 \\
(16)\end{array}$ & $\begin{array}{c}22.6 \pm 3 . \\
4\end{array}$ & 0 & $\begin{array}{c}36.6 \pm 5 . \\
9\end{array}$ & $5.8 \pm 2.3$ \\
\hline
\end{tabular}

LITERATURE CITED

Andersen, P.C., Crocker, T.E., 2016. The Fig. UF/IFAS Ext. HS27.

Bittenbender, H. C., and V. E. Smith. 2008. Growing Coffee in Hawai'i. College of Tropical Agriculture and Human Resources, University of Hawai'i, Mānoa. https://www.ctahr.hawaii.edu/oc/freepubs/pdf/coffee08.pdf

Brillinger, D.R., Preisler, H.K., Benoit, J.W., 2006. Probabilistic risk assessment for wildfires. Environmetrics 17, 623-633.

Burnham, K.P., Anderson, D.R., 2013. Model Selection and Multimodel Inference: A Practical Theoretical-Information Approach. Springer, Verlag, New York.

Cordell, S., M. Mcclellan, Y. Y. Carter, and L. J. Hadway. 2008. Towards restoration of Hawaiian tropical dry forests: the Kaupulehu outplanting programme. Pacfiic Conservation Biology 14:279-284.

Elison Timm, O., T. W. Giambelluca, and H. F. Diaz. 2014. Statistical downscaling of rainfall changes in Hawai'i based on the CMIP5 global model projections. Journal of Geophysical Research: Atmospheres 120:92-112.

Engott, J. A., 2011. A Water-Budget Model and Assessment of Groundwater Recharge for the Island of Hawai'i, U.S. Geological Survey Scientific Investigations Report 20115078.

Giambelluca, T.W., Shuai, X., Barnes, M.L., Alliss, R.J., 2014. Evapotranspiration of Hawai'i Final Report. http://evapotranspiration.geography.hawaii.edu/assets/files/PDF/ET\%20Project\%2 OFinal\%20Report.pdf

González-Rodríguez, A.M., Peters, J., 2010. Strategies of leaf expansion in Ficus carica under semiarid conditions. Plant Biology 12: 469-474.

Hijmans, R.J., Van Etten, J., 2013. Raster: geographic data analysis and modeling. R package version 2.1-49.

Ka'ūpūlehu community, H. McMillen, T. Ticktin, and N. Kurashima. 2014. Ka'ūpūlehu Local Ecological Knowledge and Climate Change 
Portal. http://hbmpweb.pbrc.hawaii.edu/kaupulehu/

LANDFIRE. 2012. Existing Vegetation Type Layer, LANDFIRE. U.S. Department of the Interior Geological Survey.

McMillen, H.L, T.Ticktin, and H.K. Springer. 2016. The Future Is behind Us: Traditional Ecological Knowledge and Resilience over Time on Hawai'i Island. Regional Environmental Change. 17 (2): 579-592.

NatureServe. 2011. International Ecological Classification Standard: Terrestrial Ecological Classifications. NatureServe Central Databases. Arlington, VA, U.S.A. Data current as of 31 July 2011.

Oksanen, J., Blanchet, F.G., Kindt, R., Legendre, P., Minchin, P.R., O'Hara, R., Simpson, G.L., Solymos, P., Stevens, M., Wagner, H., 2013. Package "vegan", R Packag ver 2.2.-1.

Pascua, P., McMillen, H., Ticktin, T., Vaughan, M., Winter, K., 2017. Beyond Services: A Process and Framework for Incorporating Cultural, Genealogical, and Place-Based Relationships into Ecosystem Service Assessments. Ecosystem Services 26B: 465475.

Pausas, J.G., Keeley, J.E., 2009. A burning story: The role of rire in the history of life. Bioscience 59: 593-601.

Pierce, A.D., Pickett, E., 2014. Building a spatial database of fire occurrence in Hawaii. Fire Management Today 74: 37-42.

Shirley, G. (ed), 2000. Invasive species in the Pacific: a technical review and draft regional strategy. Apia, Samoa.

U.S. Fish and Wildlife Service, 2015. Listed Species believed to or known to occur in Hawaii. https://ecos.fws.gov/ecp0/reports/species-listed-by-statereport?state=HI\&status=listed

Wada, C.A., Bremer, L.L., Burnett, K., Trauernicht, C., Giambelluca, T., Mandle, L., Parsons, E., Weil, C., Kurashima, N., and T. Ticktin. 2017. Estimating CostEffectiveness of Hawaiian Dry Forest Restoration Using Spatial Changes in Water Yield and Landscape Flammability Under Climate Change. Pacific Science 71(4): 401-424

Zuur, A., leno, E.N., Walker, N., Saveliev, A.A., Smith, G.M., 2009. Mixed Effects Models 
and Extensions in Ecology with R. Springer. 